\title{
CONCEPTUALIZACIÓN DE LA INEFICACIA, INVALIDEZ E INEXISTENCIA EN EL DERECHO ESPAÑOL
}

\section{CONCEPTUALIZATION OF INEFFICIENCY AND LACK DISABILITY IN SPANISH LAW}

\section{CONCEPTUALIZAÇÃO DA INEFICÁCIA, INVALIDEZ E INEXISTÊNCIA NO DIREITO ESPANHOL}

Francisca Ramón Fernández

\section{Resumen}

En el presente trabajo se pretende reflexionar sobre el concepto de ineficacia en el ordenamiento jurídico español, y su distinción con la invalidez e inexistencia contractual. El análisis de las distintas posturas doctrinales existentes no facilita una distinción unánime. Consideramos, tras el estudio de la doctrina y jurisprudencia, a la inexistencia como una categoría autónoma e independiente de la invalidez contractual, ya que es la propia norma, en este caso el Código Civil español, en diversos preceptos que analizamos, quien nos conduce a los supuestos de inexistencia contractual en los casos de falta de requisitos esenciales en el contrato, como son los casos de ausencia de consentimiento, de objeto y de causa, que serán centro de estudio detenido.

Palabras clave: ineficacia, invalidez, nulidad, consentimiento, objeto, causa.

\section{AbStRact}

In the present work one tries to think about the concept of inefficiency in the juridical Spanish classification, and his distinction with the invalidity

* Profesora de Derecho Civil, Universitat Politècnica de València (España). Dirección postal: Camino de Vera, s/n. 46022. Valencia (España). Artículo recibido el 2 de abril de 2012 y aceptado para su publicación el 3 de agosto de 2012. Correo electrónico: frarafer@ urb.upv.es 
and contractual nonexistence. The analysis of the different doctrinal existing positions does not facilitate an unanimous distinction. We consider, after the study of the doctrine and jurisprudence, to the nonexistence as a category autonomous and independent from the contractual invalidity, since it is the own norm, in this case the civil Spanish Code, in diverse rules that we analyze, the one who leads us to the suppositions of contractual nonexistence in the cases of lack of essential requirements in the contract, since they are the cases of absence of assent, of object and of reason, which will be an object of arrested study.

Keywords: Inefficiency, invalidity, nullity, consent, object, cause.

\section{RESUMO}

No presente trabalho pretendemos refletir sobre o conceito de ineficácia no ordenamento jurídico espanhol, e sua diferença com a invalidez e inexistência contratual. A análise das distintas posturas doutrinárias existentes não facilita uma distinção unânime. Consideramos, após o estudo da doutrina e jurisprudência, a inexistência como uma categoría autônoma e independente da invalidez contratual, já que é a própria norma, neste caso o Código civil espanhol, em diversos preceptos que analisamos, que nos conduz aos supostos de inexistência contratual nos casos de falta de requisitos essenciais no contrato, como são os casos de ausência de consentimento, de objeto e de causa, que serão objeto central desse estudo.

Palavras Chave: Ineficácia, invalidez, nulidade, consentimento, objeto, causa.

\section{La ineficaCia y La INVALideZ en el DeRecho Civil esPañol}

La definición de los términos 'ineficacia' e 'invalidez' ha sido una materia que siempre ha adolecido de una gran dificultad por parte de la doctrina ${ }^{1}$. La teoría clásica sobre la nulidad parte de dos categorías conceptuales: la nulidad absoluta y la anulabilidad o nulidad relativa. No obstante, el tráfico jurídico exige modernizar las teorías clásicas una vez que se superan las dificultades terminológicas. Vamos a reflejar con la mayor claridad posible los conceptos que son objeto de discusión:

${ }^{1}$ José Puig Brutau, Fundamentos de Derecho civil, Doctrina general del contrato, Barcelona, Editorial Bosch, 1954, tomo II, vol. 1º, p. 279 y ss. 
La doctrina ha insistido reiteradamente en la necesidad de diferenciar la ineficacia y la invalidez y de precisar su definición ${ }^{2}$. Según este sector se hace referencia a la ineficacia como categoría general, en el sentido de incluir los supuestos de invalidez, en referencia a falta de validez contractual, en que se han producido irregularidades o anomalías en la estructura del contrato ${ }^{3}$. En el caso de la ineficacia, la doctrina ha considerado que es un término de carácter clasificatorio e ilustrativo, pero del que no se derivan efectos jurídicos determinados ${ }^{4}$.

Sin embargo, también se ha pronunciado algún sector doctrinal en que la apreciación de ambas categorías resulta innecesaria ${ }^{5}$. Se considera

${ }^{2}$ Manuel Albaladejo García, "Invalidez de la declaración de voluntad", en Anuario de Derecho Civil, tomo x, fascículo IV, Madrid, octubre-diciembre 1957, p. 985 y ss.; Manuel Albaladejo García, El negocio jurídico, Barcelona, Editorial Bosch, 1958, p. 398 y ss.; Felipe Clemente de Diego, Instituciones de Derecho civil español, Derecho de obligaciones, Contratos, Derecho de familia, Madrid, s.n., 1959, tomo II, p. 315 y ss.; Jesús Delgado Echeverría, "Comentario al artículo 1300 del Código civil", en Manuel Albaladejo (dir.), Comentarios al Código civil y Compilaciones forales, artículos 1281 a 1314 del Código civil, Madrid, Editoriales de Derecho Reunidas, 1981, tomo XviI, vol. $2^{\circ}$, p. 231 y ss.; Jesús Delgado Echeverría, Elementos de Derecho civil, Derecho de Obligaciones, Contratos y cuasicontratos, Delito y cuasidelito, ${ }^{\text {a }}$ ed., Barcelona, Editorial Bosch, 1990, tomo II, vol. $2^{\circ}$, p. 344 y ss.; Manuel García AmigO, Lecciones de Derecho civil, Teoría general de las obligaciones y contratos, Madrid, Editorial McGraw Hill, 1995, vol. II, p. 397 y ss.; María Rosario VAlPuesta Fernández, "Ineficacia del contrato", en AA.VV., Derecho civil, Derecho de obligaciones y contratos, Valencia, Editorial Tirant lo Blanch, 2001, p. 275. Más recientemente, podemos citar las aportaciones doctrinales de Carlos Vattier Fuenzalida, "Inexistencia y nulidad del contrato", en Carlos Vattier FuenZalida, José María de la Cuesta Sáenz y José María Caballero Lozano (coords.), Código europeo de contratos: comentarios en homenaje al prof. D. José Luis de los Mozos y de los Mozos, Madrid, Dykinson, 2003, vol. 2, p. 553 y ss.; José Luis De Los Mozos y De Los Mozos, , "Inexistencia, nulidad y anulabilidad en el Anteproyecto de Código Europeo de Contratos de la Academia de Pavía”, en José Manuel GonzÁlez Porras y Fernando P. Méndez GonzÁlez (coords.), Libro Homenaje al profesor Manuel Albaladejo García, Murcia, Universidad de Murcia, 2004, vol. 2, p. 3409 y ss.; Carlos Vattier Fuenzalida, "Inexistencia y nulidad del contrato. Estudio del anteproyecto de Pavía", en Juan Manuel Abril CAmpoy y María Eulalia Amat Llari (coords.), Homenaje al profesor Lluis Puig i Ferriol, Valencia, Tirant lo Blanch, 2006, vol. 2, p. 2461 y ss.

${ }^{3}$ Pese a centrarnos en el Derecho español, interesa resaltar la aportación de la doctrina italiana, especialmente con Emilio BetTI, Teoría general del negocio jurídico, traducción y concordancias con el Derecho español por A. Martín Pérez, Madrid, Editorial Revista de Derecho Privado, 1959, p. 348 y Francesco Santoro Passareldi, Doctrinas generales del Derecho civil, traducción y concordancias de Derecho español por A. Luna Serrano, Madrid, Editorial Revista de Derecho Privado, 1964, p. 300 y ss.

${ }^{4}$ Según indica Eduardo Vázouez de Castro, Ilicitud contractual. Supuestos y efectos, Valencia, Editorial Tirant lo Blanch, 2003, p. 323, la función del concepto de invalidez no va más allá de la clarificación de algunos de los distintos y heterogéneos conceptos que se incluyen dentro de la ineficacia contractual.

${ }^{5}$ Así lo consideran, entre otros, Miguel Moreno Mocholí, "Las 'irregularidades' en el negocio jurídico", en Revista de Derecho Privado, No 346, Madrid, enero 1946, p. 26 y ss.; 
por dicha parte que la invalidez sólo es un concepto teórico, y que en el ámbito de las relaciones contractuales nos encontramos con la ineficacia ${ }^{6}$, que significa que el contrato no ha producido los efectos previstos o que preveían las partes. La falta de relevancia de efectos prácticos de la distinción entre ambos conceptos, hace inoperativa la distinción 7 .

La mayoría de la doctrina moderna ${ }^{8}$ no contrapone ambos términos, sino que entienden que su ámbito de actuación se produce en planos diferentes. Así, consideran la invalidez como causa de ineficacia, como una clase de ineficacia en los supuestos en los que ésta obedece a una sanción del ordenamiento, y que esta última sería el género y la invalidez la especie ${ }^{9}$.

En definitiva, que todo contrato inválido es ineficaz, pero no todo contrato ineficaz es inválido.

Esta premisa considera que la invalidez incluye la nulidad y la anulabilidad. Pero en los casos en el que surgen nuevas formas de sanción, que son híbridos entre las anteriores, la concepción de la invalidez no queda tan nítida. Ello ocurre en las nuevas leyes especiales que prevén nuevas formas de ineficacia y que al contemplar formas de sanción particular para el incumplimiento de los actos y contratos no van a encontrar encaje entre la invalidez.

Se establece para estos casos de inexistencia o nulidad absoluta una misma acción imprescriptible con legitimación para interponerla cualquier interesado, incluso, declararla de oficio los tribunales. Esta exposición de la ineficacia negocial se completa al contraponerla con aquélla derivada de la nulidad relativa o anulabilidad.

La jurisprudencia también ha admitido la distinción entre el supuesto de simulación absoluta o inexistencia y la ilicitud. En este sentido, la

Luis Dífz-Picazo y Ponce de León, "Eficacia e ineficacia del negocio jurídico”, en Anuario de Derecho Civil, tomo XIv, fascículo IV, Madrid, octubre-diciembre 1961, p. 824; Luis DíezPicazo y Ponce de León, Fundamentos del Derecho civil patrimonial, Introducción. Teoría del contrato, $5^{\text {a }}$ ed., Madrid, Civitas, 1996, vol. I, p. 457; Luis Díez-Picazo y Ponce De León y Antonio Gullón Ballesteros, Sistema de Derecho civil, El contrato en general. La relación obligatoria. Contratos en especial. Cuasicontratos. Enriquecimiento sin causa. Responsabilidad extracontractual, 9a ed., Madrid, Tecnos, 2002, vol. II, pp. 103-104; Luis DíEz-PicAzo y Ponce De León y Antonio Gullón Ballesteros, Sistema de Derecho civil, Introducción. Derecho de la personal. Autonomía privada. Persona jurídica, $11^{\mathrm{a}}$ ed., Madrid, Tecnos, 2003, vol. I, p. 543.

${ }^{6}$ Vázquez de Castro (n. 4), p. 323.

7 op. cit., p. 324.

${ }^{8}$ Véase, entre otros autores, Carmen Moreno Luque, "Notas sobre la eficacia e ineficacia del negocio: inexistencia, nulidad, anulabilidad y rescisión”, en Actualidad civil, No 38, Madrid, semana 13-19 de octubre 1986, p. 2621 y ss.

${ }^{9}$ María del Carmen Gete-Alonso y Calera, Manual de Derecho civil, Madrid, Marcial Pons, 1996, p. 641. 
sentencia del Tribunal Supremo de 27 de diciembre de 1966 contempló un supuesto de nulidad de una compraventa por simulación o por causa ilícita al haberse establecido un precio escriturado superior al real para perjudicar los derechos del inquilino. El arrendatario interpuso una acción basada en la impugnación del precio excesivo amparándose en el art. 53 de la LAU, lo que, según los demandados, suponía reconocer la existencia y nacimiento del contrato con todos sus elementos.

El Tribunal Supremo consideró que:

"resulta improcedente la aplicación del art. 1261 del Código Civil que se refiere estrictamente y 'a sensu contrario' a los contratos en que por faltar algunos de los requisitos que enumera, carecen de vida en Derecho, lo que aquí no sucede porque una cosa es que no exista causa y otra distinta es que ésta sea ilícita, al modo como queda expuesto; $y$ si consiguientemente, deben diferenciarse como dos acciones distintas, de un lado la de simulación que trata de demostrar la falsa apariencia de un contrato que carece de toda existencia real y de otro la de nulidad basada en la ilicitud que parte de la base de la realidad de un pacto uno de cuyos elementos -concretamente la causa, en este caso- existe pero es ilícito calificación que forzosamente tiene que apoyarse en aquella existencia, no es menos cierto que ambas acciones conducen a idéntico resultado, que no es otro sino la total ineficacia del acto celebrado con idéntico carácter retroactivo o 'ex tunc', en un caso por falta de un requisito esencial y en otro por incurrir en vicio de ilicitud, pero con el mismo valor radical y absoluto".

Se establece para estos casos de inexistencia o nulidad absoluta una misma acción imprescriptible con legitimación para interponerla cualquier interesado, incluso, declararla de oficio los tribunales. Esta exposición de la ineficacia negocial se completa al contraponerla con la que deriva de la nulidad relativa o anulabilidad ${ }^{10}$.

También, en alguna ocasión, el Tribunal Supremo pone de manifiesto la confusión de categorías como sucedió en la sentencia de 7 diciembre 1965. Se contempló un supuesto de arrendamiento y la determinación de la renta:

${ }^{10}$ Grimalt Servera, Pedro: "Nulidad y anulabilidad en el Código civil. Revisión crítica de la categoría de la anulabilidad, de acuerdo con el texto que se adjunta", en $\mathrm{Nul}$ : estudios sobre invalidez e ineficacia, $\mathrm{N}^{\circ} 1,2009$, p. 1. Se puede acceder enwww.codigo-civil. info/nulidad/lodel/docannexe.php?id=739. Consultado el 23 de agosto de 2012. 
"Para que el art. 1547 del Código Civil pueda poner fin a las divergencias sobrevenidas entre quienes verbalmente concertaron una relación arrendaticia, acerca cual sea la renta que estipularon, es menester que en el oportuno proceso se justifique debidamente por cualquiera de los medios admitidos en derecho, no sólo que entre los contratantes medió el concurso de voluntades a que se refiere el art. 1262, respecto al convenio propiamente dicho sino que, además, concurrieron en su otorgamiento cuantos requisitos se señalan al efecto, de forma genérica en el art. 1261 y especialmente en el 1543 del expresado código, porque al faltar alguno de ellos el arrendamiento sería inexistente y la solución del problema no se conseguiría a través del precepto primeramente mencionado, que para su aplicación parte de la hipótesis contraria, sino de acuerdo con las directrices que establece el art. 4 en relación con el 1255 de la misma Ley Civil sustantiva, para invalidar cuantos actos o contratos se opongan al contenido de las normas legales".

Otro de los ejemplos que podemos mencionar de sentencia en que se incide en la distinción de categorías es la sentencia del Tribunal Supremo de 14 de marzo de $1983^{11}$, que indicó expresamente:

"es doctrina, tanto jurisprudencial como científica, comúnmente admitida, que entre los grados de invalidez de los contratos se distingue la inexistencia y la nulidad radical o absoluta, según que al contrato le falte alguno o alguno de sus elementos esenciales señalados en el artículo 1261 del Código Civil o que haya sido celebrado, aún reuniendo esos elementos esenciales, en oposición a leyes imperativas cuya infracción da lugar a la ineficacia; situaciones jurídicas distintas de aquella otra en que la ineficacia deviene a consecuencia de vicios del consentimiento en la formación de la voluntad o falta de capacidad de obrar en uno de los contratantes o falsedad de la causa, caso de la denominada nulidad relativa o anulabilidad, una de cuyas consecuencias es que en este segundo supuesto la acción de nulidad dura cuatro años y sólo puede ser ejercitada por los obligados principal o subsidiariamente en vir-

${ }^{11}$ Id Cendoj: 28079110011983100026. Se puede acceder en: www.poderjudicial.es / search $/$ doAction ?action $=$ contentpdf $\&$ databasematch $=$ TS\&reference $=4410394 \&$ links $=$ inexistencia\&optimize $=19960114 \&$ publicinterface $=$ true. Consultada el 16 de agosto de 2012). Sentencia comentada por Jesús Delgado Echeverría, "Inexistencia, nulidad y anulabilidad. Usucapión: justo título. Causa ilícita. Venta de cosa ajena. Comentario STS 14 marzo 1983", en Cuadernos Civitas de Jurisprudencia Civil, No 2, Navarra, abril-agosto 1983 , p. 465 y ss. 
tud de ellos, según establecen los artículos 1301 y 1302 del citado Cuerpo legal, mientras que en los casos de inexistencia o nulidad absoluta o radical la acción es imprescriptible y puede ejercitarla cualquier tercero perjudicado por el contrato en cuestión; habiendo llegado esta Sala a declarar (sentencia de 29 de octubre de 1949) que los Tribunales pueden y deben apreciar de oficio la ineficacia $\mathrm{o}$ inexistencia de los actos radicalmente nulos.

...como se deduce de las sentencias de esta Sala de 15 de marzo de 1945 y 20 de mayo de 1957, entre otras, sin que el acto radicalmente nulo pueda ser sanable, ni convalidable (sentencias de 7 de enero de 1964 y 13 de mayo de 1970), ya que el capítulo que trata en el Código Civil de la nulidad de los contratos no se refiere a los radicalmente nulos, que deben considerarse como inexistentes y no susceptibles de confirmación, cuya ineficacia deben, incluso, como ya se indicó, apreciar de oficio los Tribunales (sentencias de 6 de marzo de 1909 y 29 de octubre de 1949, y argumento sentencia de 7 de enero de 1946)".

Esta sentencia diferencia los casos de nulidad e inexistencia de los de anulabilidad en que considera que tienen un régimen diverso.

Sin embargo, en otras sentencias del Tribunal Supremo, como la de 29 de abril de $1986^{12}$ se insiste en que la inexistencia y la nulidad absoluta tienen los mismos efectos, y en la de 24 de febrero de $1992^{13}$ se indica que la nulidad absoluta y la inexistencia son análogas y distintas a la anulabilidad:

"es doctrina reiterada de esta Sala [sentencias de 7 de octubre de 1967 (R.A., 1957, 2854), 7 de enero de 1964 (R.A., 1964, 118), 23 de octubre de 1973 (R.A., 1973, 3805), 22 de noviembre de 1983 (R.A., 1983, 6492), 17 de junio de 1986 (R.A., 1986, 3554), 22 de septiembre de 1989 (R.A., 1989, 6351)] que declarada la nulidad de un contrato procede la restitución recíproca de las cosas que hubieren sido materia del contrato, con sus frutos, y el precio con los intereses, a tenor del art. 1303 del Código Civil, habiendo declarado la Sentencia de 18 enero 1904 que 'corrobora este criterio

${ }^{12}$ Id Cendoj: 28079110011986101449. Se puede acceder en:www.poder judicial.es/ search/doAction?action $=$ contentpdf\&databasematch $=$ TS\&reference $=4397126 \&$ links $=$ ine xistencia\&optimize $=19960111 \&$ publicinterface $=$ true. Consultada el 16 de agosto de 2012.

${ }^{13}$ Id Cendoj: 28079110011992102639. Se puede acceder en: www.poderju dicial.es/ search/doAction?action $=$ contentpdf $\&$ databasematch $=$ TS\&reference $=4346201 \&$ links $=$ procede $\% 201$ la $\% 20$ restituci $\%$ F3n $\% 20$ rec $\%$ EDproca $\% 20 \mathrm{de} \% 201$ as $\% 20$ cosas $\% 20$ que $\% 20$ hubieren\&optimize $=19960105 \&$ publicinterface $=$ true. Consultada el 22 de agosto de 2012. 
la jurisprudencia de esta Sala, referida a la nulidad absoluta o inexistencia, que ha declarado que las restituciones a que se refiere el art. 1303 sólo proceden, incluso tratándose de contrato nulo o inexistente, cuando ha sido declarada la nulidad', obligación de devolver que no nace del contrato anulado, sino de la Ley que la establece en este contrato [sentencia 10 de junio de 1952 (RLA., 1952, 1255)], por el cual no necesita de petición expresa de la parte pudiendo ser declarada por el Juez en cumplimiento del principio 'iura novit curia', sin que ello suponga alterar la armonía entre lo pedido y lo concedido, y con la finalidad de evitar, sin necesidad de acudir a un nuevo pleito, el enriquecimiento injusto de una de las partes a costa de la otra (sentencia 22 de noviembre de 1983)".

También encontramos alguna ocasión en que se ha recogido el concepto de inexistencia como una "variedad" de invalidez junto a la nulidad absoluta y la anulabilidad. Es el caso de la sentencia del Tribunal Supremo de 18 de diciembre de $1981^{14}$, al indicar:

"la invalidez tiene lugar cuando no reúne un acto las condiciones requeridas por la ley, con la distinción de los actos inválidos en inexistentes, en los de pleno derecho y anulables, con la característica de inexistencia a los que están faltos de un órgano constitutivo y no responden a su propia definición, de nulidad de pleno derecho a los que, dotados de sus elementos constitutivos, chocan con una regla de orden público, y simple anulabilidad los que han sido concluidos bajo el imperio de uno de los vicios del consentimiento, tomados en consideración por la ley".

El concepto de la inexistencia se utiliza por la jurisprudencia para aplicarlo a contratos simulados, evitando la caducidad de la acción del art. 1300 y ss. del Código Civil. Como se encarga de señalar la doctrina ${ }^{15}$, esta institución está encaminada a dar fijeza y certidumbre a la propiedad y a toda clase de derechos emanados de las relaciones y de las condiciones en las que se desarrolla la vida, aun cuando éstas no se ajusten siempre a verdadera justicia, que hay que subordinar, como mal menor, al que resultaría de la inseguridad jurídica de una inestabilidad indefinida. El mero transcurso del tiempo no puede cambiar la naturaleza jurídica de

${ }^{14}$ Id Cendoj: 28079110011981100284. Se puede acceder en: www.poder judicial.es/ search/doAction?action $=$ contentpdf\&databasematch $=$ TS\&reference $=4414989 \&$ links $=\& o$ ptimize $=19960116 \&$ publicinterface=true. Consultada el 16 de agosto de 2012.

${ }^{15}$ VázQuez de Castro (n. 4), p. 339, n. 127. 
los actos que han de evaluarse en Derecho, por lo que, lo inexistente no alcanza realidad y del mismo modo se ha de entender que ni lo ilícito ni lo inmoral se purifican de sus defectos por el transcurso del tiempo. Esto no aparece precisamente recogido en el texto del Código Civil, ya que el art. 1930.2 declara la prescriptibilidad de todos los derechos y acciones, y en los arts. 1303 y 1306 del mismo texto legal se establecen las obligaciones de las partes para deshacer los efectos de los contratos nulos, sin establecer que las oportunas acciones restitutorias sean imprescriptibles cuyo carácter reconoce el Código Civil sólo a las que enumera en su art. 1965, en consecuencia, serían aplicables los arts. 1961 y 1964, que establecen la prescripción en el plazo de quince años. Si distinguimos la acción declarativa de nulidad de la restitutoria a la que da lugar y decimos que el principio de que la nulidad es imprescriptible se refiere a la acción declarativa exclusivamente sólo para destruir la apariencia de validez creada para el caso en el que no se hubiesen ejecutado aún las prestaciones.

En la actualidad vemos que la utilización del concepto de inexistencia se utiliza junto al término de 'ilicitud' y de 'nulidad' para conceder mayor intensidad a la sanción. Es una realidad que la jurisprudencia, pese a haberlo intentado, no ha logrado definir con la exactitud deseada el fino límite entre la nulidad y la inexistencia. Por eso, nos encontramos con sentencias en los que se confunden ambos términos.

\section{INEXISTENCIA, NULIDAD E ILEGALIDAD}

La concepción más clásica de la ilicitud confunde los conceptos de inexistencia, nulidad e ilegalidad. La confusión se origina porque se parte de la consideración de que es la ley prohibitiva perfecta la única que tiene capacidad para calificar como ilegal a un contrato. Cuando debería referirse a la nulidad y no a la ilegalidad que puede provocarla cualquier ley imperativa o prohibitiva ${ }^{16}$.

Es frecuente que se produzca la confusión entre la causa (ilegalidad o inexistencia) con la consecuencia (nulidad) ${ }^{17}$. También presenta dificultades la cuestión de que el término 'nulidad' se emplea para significar dos conceptos distintos: en un sentido estricto se utiliza para designar a la nulidad de pleno derecho, que algunos autores identifican o asimilan con la inexistencia, y en un sentido amplio se utiliza para referirse a la

${ }^{16}$ Francesco Ferrara, Teoría del negozio illecito nel diritto civile italiano, $2^{\mathrm{a}}$ ed., Milano, Societa Editrice Libraria, 1914, p. 20 y ss.

${ }^{17}$ Se observa la confusión en Jaime SANTos BRIz, Derecho civil. Teoría y práctica, Madrid, Editorial Edersa, 1978, tomo I, p. 673 y ss. 
ineficacia de forma general y se asimila a la ilicitud. Por tanto, es preciso que diferenciemos la inexistencia, la nulidad y la ilegalidad.

La confusión se suele producir entre la inexistencia y la nulidad y de ambas con la ilicitud por violación de una norma ${ }^{18}$.

La función que cumplen tanto la verificación de la inexistencia como la ilegalidad es el de control de mínimo exigibles para la eficacia de un contrato. Por esa razón, ambas son motivos concebidos por el ordenamiento jurídico como fundamento o base sobre el que puede llegar a producirse o verificarse la nulidad de este instrumento. El efecto de la nulidad puede llegar como consecuencia de la contravención por el contrato de una norma jurídica imperativa o prohibitiva. Siguiendo esta postura ${ }^{19}$, tanto la ilegalidad como la inexistencia provocarían la nulidad.

La ilegalidad va a perseguir siempre una finalidad concreta que marcará el legislador y producirá una ineficacia funcional, que no siempre tendrá como resultado la nulidad de pleno derecho.

El problema de la nulidad en cuanto fruto de la ilegalidad deriva de la autonomía privada y sus límites y pertenece a la dinámica del negocio jurídico. Debe atenderse a las normas que rigen la disciplina del mismo y no las que configuran su estructura.

Para esta postura no es cierto que los contratos en que falta alguno de los requisitos del art. 1261 del Código Civil estén sujetos a la misma disciplina que los contrarios a las leyes.

Tampoco que la ilegalidad sea un sinónimo de nulidad. No resulta útil la distinción terminológica si con ello se tiende meramente a identificar la licitud con la nulidad de pleno derecho, diferenciándola de la inexistencia sólo en que ésta se reserva para los casos de carencia de un requisito esencial. Esta distinción tampoco tiene resultados positivos para evitar las consecuencias negativas de la tendencia práctica de la falta de flexibilidad a la hora de establecer sanciones de las ilegalidades en los contratos. No pueden equipararse siempre los efectos de la inexistencia y de los contratos ilegales ${ }^{20}$.

${ }^{18}$ Miguel Pasquau Liaño, Nulidad y anulabilidad del contrato, Madrid, Editorial Civitas, 1997, p. 164 y ss.

${ }^{19}$ Sigo en la exposición los argumentos expuestos por VÁzQuez de CaSTRo (n. 5), p. 332.

${ }^{20}$ Manuel Amorós Guardiola, Comentarios a las reformas del Código Civil, Madrid, Editorial Tecnos, 1977, vol. I, p. 331, al respecto afirma: "nulidad que no implica inexistencia, sino simplemente carencia de los efectos voluntariamente queridos cuando son distintos a la finalidad protegida por la ley. Esta será eficaz a pesar del acto realizado por los particulares en contra de su mandato. Lo cual no significa, obviamente, que dicho acto nulo no produzca ciertas consecuencias: al menos, las resultantes de la sanción correspondiente que además de la nulidad, podrá comportar una pena, una responsabilidad civil o administrativa, etc., o la que en definitiva resulte de la propia ley incumplida”. 
Resulta imprescindible diferenciar la nulidad radical y la ilegalidad. La ilicitud o ilegalidad es otra de las causas de nulidad. La diferencia estriba en que mientras la inexistencia es siempre y en todo caso causa de nulidad, la ilicitud puede ser causa de nulidad, pero no necesariamente (ineficacia derivada de un control funcional).

Ello no significa que se identifiquen la ilicitud, nulidad o la inexistencia, porque la ilicitud no constituye una mera categoría conceptual de la ineficacia, sino que se trata de una calificación autónoma.

La ilegalidad está marcada por políticas que van a responder a exigencias y necesidades de tipo social. Es interesante observar las soluciones que se dan en el caso de la infracción de legislación con contenidos de tipo social o normativas que tienen una finalidad tuitiva para los contratantes. La ineficacia del contrato que transgrede la legislación debe adaptarse a la función o finalidad que se persigue y será siempre de carácter funcional

La vulneración de algún tipo de esta normativa no se puede considerar de antemano con las mismas consecuencias que la inexistencia, aunque la ilegalidad recaiga sobre algún elemento esencial del contrato, que, casi siempre será inevitable ${ }^{21}$.

${ }^{21}$ VÁzQuez de CASTRo (n. 4), p. 335, n. 113. Este autor nos expone un ejemplo claramente representativo de dicha situación: "el caso de las viviendas de protección oficial cuyos contratos de compraventa tienen fijado un precio superior al legalmente tasado. El precio es un elemento esencial del contrato de compraventa, en general incardinado dentro del art. 1261 CC: es parte del objeto y causa de la contraprestación (art. 1274) y, además, es elemento esencial específico en la compraventa (art. 1445) donde se exige que sea cierto y en dinero. Al pactarse un precio superior al tasado en la Ley, para empezar, el contrato ya existe con lo cual no va a ser nulo por inexistente. Partiendo de este presupuesto, habrá que ver la naturaleza de la ilegalidad de ese elemento esencial. $1^{\circ}$ acudimos al art. $1271 \mathrm{CC}$ el dinero no es un objeto que se encuentre fuera del comercio de los hombres con lo que este art. no es infringido. $2^{\circ}$ el precio en principio es cierto con lo cual nos encontramos en principio vicio estructural que pueda llevarnos a la nulidad ahora habrá que evaluar la ilegalidad de la causa, para ello hemos de acudir a los art. 6.3 CC y a la normativa sobre VPO y contrastarlo con los arts. 1255 y 1275 CC. No por el hecho de afectar el vicio de ilegalidad a un elemento esencial del contrato tiene que producir necesariamente la nulidad radical porque el parámetro para medir las consecuencias de esa ilegalidad nos viene ordenado en el art. 6.3 (actos contra legem) donde, si bien establece una sanción general de nulidad, a renglón seguido, nos ofrece posibilidades de excepción a la nulidad de pleno derecho que habrá que estudiar en cada caso. La posibilidad de excepción se ha de encontrar en la propia norma infringida. Para ello se ha de atender no solo al tenor literal de su redacción sino que habrá que realizar una labor interpretativa (como la hecha para ver si es una norma imperativa). Ahora, para ver cuál es el significado real de esos términos de imperatividad en los que se expresa y tratar de encontrar para el caso de contravención convencional el efecto más ajustado a la ratio iuris del precepto. Las corrientes jurisprudenciales que predominan actualmente se han decantado sobre el particular, en ningún caso adoptando como solución la nulidad absoluta, sino más bien por mantener ciertos efectos del contrato, bien sea proclamando su nulidad parcial, bien sea incluso manteniendo su validez civil íntegramente". 
La inexistencia propiamente dicha, entendida como la ausencia de un componente intrínseco del supuesto de hecho contractual no se identifica ni en su estructura, ni en su funcionamiento con el acto contra legem ${ }^{22}$.

Un contrato ilegal tiene que existir ${ }^{23}$. Por tanto, tienen que darse todos los requisitos del art. 1261 del Código Civil. Tiene que cumplir con todos los requisitos esenciales específicos de cada tipo contractual.

Según esta postura, la inexistencia y la ilicitud no vendrían a ser sino dos causas distintas de la nulidad. La inexistencia derivaría a una nulidad radical o de pleno derecho, mientras que la ilegalidad tiene un abanico mayor de posibilidades.

Otra diferencia la encontramos si atendemos al tipo de ley que resulta infringida. La doctrina italiana utiliza el concepto de fatispecie. Su significado vendría a entenderse como la cierta tipicidad que se exige a los contratos para su validez.

Parten de la concepción de que como los elementos constitutivos esenciales de estos instrumentos son establecidos por leyes, éstas se pueden considerar que recogen los requisitos de existencia y se han de diferenciar de otras que establecen requisitos de legalidad o licitud de un contrato ya existente. Las normas constituyentes son las que conducirían a la inexistencia y las normas de conducta serían las que llevarían a la $74 \quad$ ilegalidad de este tipo de convenciones ${ }^{24}$.

Se distingue entre las normas que establecen los requisitos o elementos esenciales del contrato leggi ordinative cuya desobediencia no llevaría a considerarlo como ilícito, sino a un negocio que no lleva a ser completo y perfecto ${ }^{25}$.

En este tipo de leyes no se constriñe materialmente la acción del individuo, sino que se subordina su protección a la observancia de ciertas condiciones, requisitos materiales y formales que deben integrar el negocio para que sea acogido en el campo jurídico ${ }^{26}$.

En las leggi imperative si falta una circunstancia de hecho que integra el momento esencial de la prohibición, el contrato primitivo adquiriría vigor. En el caso de las leggi ordinative cualquier falta provoca que sea un negocio no nacido, no puede tener fuerza jurídica si no se le completa. Es el caso del requisito de la escritura pública en la donación de inmuebles

${ }^{22}$ Antonio Gordillo CaÑas, "Nulidad, anulabilidad e inexistencia (El sistema de las nulidades en un Código latino situado entre la primera y la segunda Codificación)", en Centro de Estudios Ramón Areces (ed.), Centenario del Código civil (1889-1989), Madrid, Editorial Ramón Areces, 1990, tomo I, p. 935 y ss.

${ }^{23}$ Ferrara (n. 16), p. 2 y ss.

${ }^{24}$ VázQuez de Castro (n. 4), p. 336.

${ }^{25}$ Ferrara (n. 16), p. 19.

${ }^{26}$ Op. cit., p. 17 y ss. 
y del precio en la compraventa como ejemplo de normas ordinative y la prohibición de donaciones entre cónyuges y la venta de bienes litigiosos a un oficial o funcionario público como norma imperative ${ }^{27}$.

La ilegalidad del contrato además de ser potencialmente una posible causa de nulidad y sus consecuencias naturales, también es cierto que encuentra cada vez mayores excepciones.

La noción de contrato inexistente no resulta más que un intento de extender la aplicación de la nulidad radical para romper con ella los prejuicios de concepciones estrechas del legalismo y formalismo ${ }^{28}$.

\section{CONTRATO ILEGAL, INEXISTENTE E IMPERFECTO}

La primera distinción que conviene que realicemos es qué se entiende por contrato ilegal. Para lograr acercarnos a una definición, hemos de advertir que este concepto ha sido en ocasiones utilizado como sinónimo de contrato ilícito. Formarían parte de un concepto extenso en el que se incluirían los negocios en los que los contratantes se exceden de cualquiera de los tres límites a los que se debe someter la autonomía de la voluntad ${ }^{29}$.

Pero si concretamos un poco más, lo entendemos como al rechazado en todo o en parte por el Derecho Positivo. Tomaríamos como referente para considerarlo el límite legal o normativo. De esta forma, un contrato ilegal exigiría que existiera una contravención del mismo o su eficacia con la norma ${ }^{30}$.

Se lo definiría como aquél cuyo contenido es el que resulta rechazado en todo o en parte, por una norma jurídica imperativa o prohibitiva ${ }^{31}$.

${ }^{27}$ Ferrara (n. 16), p. 20 y ss.

${ }^{28}$ VÁzQuez de Castro (n. 4), p. 337.

${ }^{29}$ VÁzQuez de Castro (n. 4), p. 39, estima que esta concepción no sólo incluye el límite legal (normas jurídicas) como referente para la consideración de un contrato como ilegal sino, también, los límites extrapositivos (reglas morales y de orden público). Estos términos en su sentido más genérico se pueden referir a los contratos rechazados en todo o en parte por cualquier elemento del ordenamiento jurídico en general.

${ }^{30}$ VázQuez de Castro (n. 4), p. 39.

${ }^{31}$ Se reduce, considerablemente, el campo de referencia del contrato ilegal. José Luis Lacruz Berdejo, Francisco de Asís Sancho Rebullida, Agustín Luna Serrano, Jesús Delgado Echeverría, Francisco Rivero Hernández y Joaquín Rams Albesa, Elementos de Derecho civil, Derecho de Obligaciones, Contratos y cuasicontratos. Delito y cuasidelito, Madrid, Dykinyson, 2005, tomo II, vol. $2^{\circ}$, p. 180 y ss., considera que son ilegales las estipulaciones directamente reprobadas por la ley. Sin embargo, partidario de una concepción más amplia de contrato ilegal nos la proporcionaría SANTOS BRIZ (n. 17), p. 610, al considerar que los negocios ilegales son los que infringen normas coactivas o los principios generales del derecho en que se funda la tutela del orden público. 
La existencia de una irregularidad en el contrato para que sea ilegal no se puede considerar que sea "cualquier irregularidad", ya que el calificativo de ilegal se origina en el momento en el que existe una norma jurídica que dispone la necesidad de que las relaciones contractuales se deban desarrollar de acuerdo con unas pautas que resulten no compatibles con lo que hayan dispuesto los contratantes.

El contrato ilegal es uno que se halla dentro del ámbito y cumple los presupuestos de la autonomía privada, pero existe dentro de esa autonomía privada un límite legal que mediante una prohibición o un mandato reprueban en un caso particular este instrumento que, de otra manera, sería en potencia eficaz ${ }^{32}$.

Definido así, es preciso distinguirlo del contrato inexistente y del imperfecto.

El contrato ilegal va a ser uno en el que:

a) La declaración de voluntad ha de ser manifestada adecuadamente y el acuerdo ha de ser sustancialmente perfecto.

b) La ilegalidad abarcaría dentro de esa ilicitud (que implica una ofensa contra el ordenamiento jurídico) el ir en contra de una norma jurídica imperativa o prohibitiva, según preceptúa el art. 6.3 del Código Civil.

c) Va a tener que existir. Se parte de la premisa de la existencia del mismo al que se trata de descubrir un vicio de ilicitud.

d) No significa que carezca de uno de los elementos esenciales que se tiene que dar en todo contrato. La falta de uno de los requisitos mencionados en el art. 1261 del Código Civilo los que se establezcan en particular para alguno especial, no dará lugar a una ilicitud del contrato sino que a uno inexistente.

e) El hecho de que sea ilícito no significa que ese contrato sea inexistente, ya que tiene todos los requisitos necesarios para nacer, para existir.

El contrato es perfecto, lo que sucede es que el ordenamiento jurídico (la ley en el caso del considerado ilegal) se opone a su contenido o a los efectos pretendidos por alguna o ambas partes contratantes ${ }^{33}$.

f) Partiendo de la concepción de contrato ilegal en sentido estricto, no se considerará como ilegal a aquéllos en los que se ignora alguna de las formalidades.

${ }^{32}$ Así lo caracteriza el negocio prohibido Karl Larenz, Tratado de Derecho civil alemán, traducción Miguel Izquierdo, Madrid, Editorial Revista de Derecho Privado, 1978, Parte general, p. 587.

${ }^{33}$ Vázquez de Castro (n. 4), p. 47. 
Los contratos imperfectos son los que adolecen de algún vicio permanente e intrínseco que vienen a coincidir con un fallo del presupuesto de la libertad contractual. Serían especialmente aquellos casos en los que no se cumplen los requisitos de capacidad y del consentimiento.

Éstos no serían ilícitos o ilegales salvo en los supuestos en los que se viera amenazada la premisa de la igualdad de los contratantes.

No obstante lo anterior, algún autor ha considerado que los contratos con causa ilícita se incluirían dentro de la clasificación de los que se estiman imperfectos, ya que obedecen con mayor nitidez al perfil de la ilicitud que al de la imperfección. Los efectos que se derivarán de la imperfección serán la anulabilidad o nulidad relativa.

\section{Tratamiento en el Código CiVIl de la ineXistencia}

En el texto original del Anteproyecto de libro IV del Código Civilse incluía un precepto nuevo procedente del Proyecto de Laurent en el que al referirse a la confirmación se aludía expresamente al concepto de inexistencia. Es el primitivo art. 1323 del Anteproyecto que luego sería el art. 1310.

El art. 1323 del Anteproyecto disponía:

"Sólo son confirmables los contratos existentes conforme al art. 1274. De los convenios en que falte cualquiera de los requisitos mencionados en este artículo, no nace acción alguna contra los que aparezcan obligados" ${ }^{\prime 4}$.

La noción de inexistencia servirá para clarificar la extendida confusión terminológica y conceptual que en materia de ineficacia se arrastraba desde la época romana. Al entrar en vigor el Código Civil se produce una confusión en lo referente al tratamiento de este tema y de todos los conceptos que la implicaban en la práctica. Se aprecia, en dicho momento y también en la actualidad, una preocupación de la doctrina y jurisprudencia, para fijar los conceptos y régimen jurídico de las diferentes categorías de ineficacia que aparecían en el tráfico jurídico y que no encontraban una precisión adecuada en el texto del Código $o^{35}$.

$\mathrm{Al}$ igual que sucede en la mayoría de los códigos civiles europeos que no nos ofrecen una definición de los diferentes fenómenos de ineficacia que pueden observarse a lo largo de su articulado, el Código Civil tampoco

${ }^{34}$ Juan Francisco Lasso Gaite, Crónica de la codificación española, codificación civil (génesis e historia del Código), Madrid, Editorial Ministerio de Justicia, Comisión General de Codificación, 1970, vol. II, N 4, p. 674.

${ }^{35}$ VÁzQuez de Castro (n. 4), p. 296. 
nos proporciona una definición. Esta ausencia es considerada por la doctrina como positiva, porque sería inútil e inoportuna en un texto legal ${ }^{36}, y$ hubiera supuesto un peligro ya que hubiese significado un límite dañoso para su aplicación en los casos concretos ${ }^{37}$.

No obstante, sí que resulta útil y oportuno que se deslinden y caractericen los casos y condiciones en los que se debe aplicar cada régimen de ineficacia que recogen. Debía de establecerse una regulación clara y una precisión terminológica tanto del concepto general de cada tipo, como del régimen que se aplicara en cada supuesto ${ }^{38}$.

Este presupuesto no se cumple en el articulado del Código Civil, ya que no nos aporta una comprensión y precisión de los diferentes supuestos; al contrario, la terminología que emplea es confusa e imperfecta. Ello ha derivado que lo distintos autores que han tratado la materia hayan utilizado con una gran imprecisión los términos de ineficacia, inexistencia, invalidez, nulidad, anulabilidad, rescisión, resolución, etcétera ${ }^{39}$.

Se va a producir una antigua confusión ${ }^{40}$ que se hará mucho más patente entre los conceptos de nulidad y anulabilidad. La propia sistemática del Código Civil llevaría a la conclusión de que no existían sino dos tipos de ineficacia: la nulidad y la rescisión. Las razones son las siguientes:

a) La terminología que emplea el propio articulado: nulidad y rescisión son los dos únicos conceptos empleados en el Código Civil.

b) La confusión se origina porque se mezclan en el capítulo VI denominado "De la nulidad en los contratos", dos modelos o sistemas distintos de ineficacia ${ }^{41}$.

La aspiración de que en el Proyecto de 1851 se distinguiera con mayor nitidez la nulidad de la anulabilidad no se verá cristalizada en el texto del Código Civilde $1889^{42}$. La razón es que el Código Civilno materializa en su

${ }^{36}$ VÁzQuez de Castro (n. 4), p. 296.

${ }^{37}$ Livio Rattin, Sugli effetti dei negozi nulli, Bologna, Editoriale Pàtron, 1983, p. 41.

${ }^{38}$ Vázquez de Castro (n. 4), p. 296.

${ }^{39}$ José Castán Tobeñas, Derecho civil español, común y foral, reimpresión de la $14^{\mathrm{a}}$ ed., revisada y puesta al día por José Luis de los Mozos, Madrid, Editorial Reus, 1987, tomo I: Introducción y parte general, Teoría de la relación jurídica. La persona y los derechos de la personalidad. Las cosas. Los hechos jurídicos, vol. $2^{\circ}$, p. 931, se refiere a la nulidad de los actos y negocios jurídicos como uno de los conceptos más confusos del Derecho Civil.

${ }^{40}$ Como indica VázQuez de Castro (n. 4), p. 296, esta confusión está perfectamente superada por los autores modernos, pero, incluso, como puso de manifiesto Federico de Castro, llegó a filtrarse en alguna sentencia del Tribunal Supremo, aunque por lo general la jurisprudencia supo marcar el deslinde entre la nulidad y la anulabilidad.

${ }^{41}$ Federico de Castro y Bravo, El negocio jurídico, Madrid, Editorial Civitas, 1971, p. 249 y ss.; José María Planas y Casals, Derecho civil español común y foral, Barcelona, Editorial Librería Bosch, 1925, tomo II, p. 236 y ss.

${ }^{42}$ Víctor Lavandera y Blanco, "Nulidad, anulabilidad y rescindibilidad en el Código civil”, en Revista de Derecho Privado, No 6, Madrid, 15 de marzo de 1914, p. 178. 
texto la distinción del Derecho Romano entre nulidad y anulabilidad, cuya aparición es más tardía y se considera una forma de protección acordada por el pretor en los casos de un contrato válido porque cumplía todos los requisitos del Derecho Civil, pero que causa un perjuicio a uno de los contratantes porque medió violencia o era menor de veinticinco años y fue engañado, abusando de su inexperiencia (D. 4,4,1,1).

El Código Civil denominará nulidad tanto a la nulidad absoluta (art. $6.3)^{43}$ como a la relativa o anulabilidad (arts. 1300-1314).

Con este panorama de confusión terminológica y para intentar arrojar un poco de luz se acudió a una nueva figura de ineficacia que se denominó inexistencia.

El término no es novo, sino que lo habíamos encontrado ya en el Derecho Romano con un significado análogo a la nulidad. En este Derecho se partía de la tesis de que un negocio o era perfecto o no existía. El pretor inducido por las exigencias de la práctica superaba este concepto y concedía remedios idóneos para remover o paralizar los efectos de un negocio, que era válido para la normativa civil, pero que estaban afectados por vicios que perturbaban algunos de sus elementos.

En el Derecho Justinianeo cuando se fusionan el ius civile y el ius honorarium se conserva la distinción entre nulidad y anulabilidad, para identificar los negocios carentes de algunos de sus requisitos esenciales y los negocios que tienen todos esos requisitos, pero que algunos de ellos tiene un vicio ${ }^{44}$.

El término lo acogió la jurisprudencia francesa para su utilización como medio para huir de la rigidez de la nulidad textual o expresa. El concepto no nace, sino que surge de la rama del Derecho matrimonial, habiendo sido atribuido por algunos autores franceses a Napoleón ${ }^{45}$. Es lo que se denominó la consolidación de la regla pas de nullité sans texte.

${ }^{43}$ Como indica Belén CASAdo CASAdo, "El art. 6.3 CC, ¿punto de partida para el establecimiento de un régimen sancionador en el Código Civil?", en Nul: estudios sobre invalidez e ineficacia, $\mathrm{N}^{\mathrm{o}} 1$, ejemplar dedicado a Coloquios, 2006, p. 1 y ss. Se puede acceder en: www.codigo-civil.info/nulidad/lodel/document.php?id=229. Consultado el 22 de agosto de 2012, "pese a la incertidumbre que rodea algunos de los términos que aparecen en este precepto, hay una cuestión más o menos clara y que así resulta defendida por la mayoría de la doctrina. Esta nulidad de pleno derecho a que hace referencia el artículo que comentamos es la nulidad absoluta, por contraposición a otros regímenes de ineficacia contractual tales como la anulabilidad".

${ }^{44}$ Salvatore Di Marzo, Le basi romanistiche del Codice Civile, Torino, Editoriale Unione Tipográfica-Editrice, 1950, p. 259.

${ }^{45}$ Cirilo Martín Retortillo, "Algo sobre las acciones de inexistencia en el Derecho civil”, en Pedro Font y Puig, Estudios Jurídicos, conferencias de los cursillos de los años 1950 y 1951 del Colegio Notarial de Barcelona, Barcelona, Colegio Notarial de Barcelona, 1959, p. 35 y ss. 
En nuestro país se utiliza el término 'inexistencia' como sinónimo de la nulidad radical o de pleno derecho para distinguir sus efectos de la anulabilidad, que nuestro ordenamiento no distinguía ${ }^{46}$, con respecto a la terminología, y evitar los plazos de la acción de anulabilidad haciendo la acción imprescriptible, además de absoluta ${ }^{47}$. Será, sin embargo, la doctrina italiana $^{48}$ la que se esfuerce en diferenciar la nulidad y la inexistencia ${ }^{49}$, más aún que el sector patrio.

Superada esa regla, la noción de inexistencia coincidiría con la de nulidad absoluta contraponiéndola a la nulidad relativa o anulabilidad ${ }^{50}$.

Algunos autores patrios introducen ${ }^{51}$ la tipología de la inexistencia y posteriormente se generaliza por parte de nuestra doctrina.

En nuestro Código Civil se puede deducir un concepto de inexistencia de la interpretación de los arts. 1261 y 1275, en relación con los arts. 1300 y 1310 de nuestro texto legal. Según la mayoría de los autores, esta deducción fue un recurso doctrinal y jurisprudencial para poder escapar, en los casos de nulidad radical, del régimen jurídico de la nulidad relativa o anulabilidad que observaba el Código Civil. Era necesario diferenciar los supuestos de inexistencia y de nulidad relativa en cuanto al plazo y la legitimación. Ello se conseguía con una figura que tuviera una denominación distinta a la de la nulidad relativa o anulabilidad. Esta nueva figura superaba la confusión que se apreciaba en el Código Civil, pues, en

${ }^{46}$ VÁzQuez de Castro (n. 4), p. 329, considera que la previsión de la nulidad como regla general aplicable a la ilegalidad o ilicitud (en sentido más amplio) sirvió como referencia para la configuración dogmática de la nulidad radical o absoluta y su distinción de la nulidad relativa o anulabilidad.

${ }^{47}$ José Puig Brutau, Diccionario de acciones en Derecho civil español, Barcelona, Editorial Bosch, 1984, p. 199.

${ }^{48}$ Véase, Rómulo Morales Hervías, "Inexistencia y nulidad analizadas desde el punto de vista de los derechos italiano, español y peruano", en Nul: estudios sobre invalidez e ineficacia, ejemplar dedicado a estudios, $\mathrm{N}^{\circ} 1,2005$. Se puede acceder en: www.codigocivil.info/nulidad/lodel/document.php?id=129. Consultado el 22 de agosto de 2012.

${ }^{49}$ Jesús Delgado Echeverría y M Ma Ángeles, PArra Lucán, Las nulidades de los contratos. En la teoría y en la práctica, Madrid, Dykinson, 2005, p. 43.

${ }^{50}$ Antonio María Borrell y Soler, La nulidad de los actos jurídicos según el Código civil español, Barcelona, Editorial Bosch, 1947, p. 8 y ss. Por su parte, CASADO CASAdo (n. 43), p. 2, sostiene que la figura de la nulidad parcial, pese a carecer de reconocimiento legal, ha sido reconocida por la jurisprudencia y la doctrina como figura autónoma, con existencia en sí misma, y no como una minoración o suavización de la aplicación de la nulidad absoluta.

${ }^{51}$ Se atribuye a Castán Tobeñas (n. 30), p. 940, la introducción de la tipología en nuestra doctrina. Según este autor: "En nuestro Código Civil no aparece el término inexistencia (pues solo se habla, en general, de actos nulos), ni está reglamentada esta especie de nulidad. Pero no cabe duda que diversos artículos, especialmente el 1261 y el 1310 reconocen implícitamente, la distinción entre ella y la simple anulabilidad. Por otra parte, la jurisprudencia admite dicha distinción sin vacilaciones". 
algunas ocasiones, se refería a supuestos de nulidad, pero sin distinguir de qué tipo de nulidad se trataba; se producía una imprecisión terminológica, con lo que no se distinguía netamente los casos en los que se trataba de nulidad radical y de anulabilidad o nulidad relativa ${ }^{52}$.

Aunque la imprecisión haya sido superada por la doctrina y la jurisprudencia ${ }^{53}$, podemos, todavía, encontrar referencia a dicha imprecisión en la jurisprudencia actual. Ejemplo de ello es la sentencia del Tribunal Supremo de 27 de febrero de $1997^{54}$, en la que hace referencia a la imprecisión terminológica del Código Civil en los arts. 1300, 1301 y 1302:

“...el capítulo del Código civil en que se encuentran enclavados los artículos que se dicen infringidos, regula la nulidad de los contratos; pero para centrar la cuestión, hay que proclamar que la terminología empleada en la normativa referenciada, es muy imprecisa, por eso se ha discutido si cuando en dichos artículos se habla de nulidad, ha de entenderse la misma, como de inexistencia contractual, de nulidad 'ab radice' o de simple anulabilidad. Dicha cuestión, ya prácticamente ha sido solventada por la doctrina, y por una casi constante jurisprudencia de esta Sala que entiende que la tacha reflejada por dichos artículos ha de entenderse como de anulabilidad en el sentido de una clase de invalidez dirigida a la protección de un determinado sujeto, de manera que únicamente él puede alegarla y así mismo optar por convalidar el contrato anulable mediante confirmación. Dicho con otras palabras, que hay que estimar a dichos contratos anulables como inicialmente eficaces, pero eso sí, con una eficacia claudicante”.

Como hemos indicado, el término 'inexistencia' se acuña como una figura para superar la imprecisión terminológica del Código Civil en los

${ }^{52}$ Cfr. Domingo de Morató, Derecho civil español con las correspondencias del Derecho romano, Valladolid, Editorial Imprenta, Librería Nacional y Extrangera de Hijos de Rodríguez, Libreros de la Universidad y del Instituto, 1877, p. 333 y ss.; Modesto Falcón, Código civil español, Madrid, Editorial Góngora, 1889, tomo IV, p. 128 y ss.; León Bonel Y SÁnchez, Código civil español comentado y concordado, Barcelona, López Robert (ed.), 1891, tomo IV, libro IV, p. 278 y ss.; Calixto Valverde y Valverde, Tratado de Derecho civil Español, Valladolid-Madrid, Editorial Cuesta, 1913, tomo III: Parte especial, Derechos personales o de obligaciones, p. 290 y ss.; Planas y Casals (n. 41), p. 236 y ss.; Ricardo Oyuelos, Principios, doctrina y jurisprudencia referentes al Código civil español, Madrid, Editorial Cuerpo del Derecho Español, 1928, tomo v, p. 473 y ss.

${ }^{53}$ María Ángeles Egusquiza Balmaseda, Cuestiones conflictivas en el régimen de la nulidad y la anulabilidad del contrato, Navarra, Editorial Aranzadi, 1999, p. 15 y ss.

${ }^{54}$ Id Cendoj: 28079110011997101400. Se puede acceder en: www.poderjudicial.es/ search $/$ doAction ?action $=$ contentpdf $\&$ databasematch $=$ TS\&reference $=2339142 \&$ links $=r$ adice\&optimize $=20040521 \&$ publicinterface $=$ true. Consultada el 16 de agosto de 2012 . 
términos de nulidad absoluta y relativa. En los casos en los que se consideraba que existía nulidad absoluta se calificaba como de "inexistencia", ya que si se calificaba como "nulidad" a secas se corría el riesgo de aplicarse el régimen jurídico de la nulidad relativa o anulabilidad ${ }^{55}$.

En definitiva, la distinción de los distintos regímenes de ineficacia se produce como consecuencia de la derivación de la nulidad radical en los casos de ilegalidad contractual, a raíz de su deducción del antiguo art. 4 del Código Civil. Esta nulidad es identificada con la inexistencia, como hemos observado en la interpretación de los autores ${ }^{56}$.

Una vez que se supera la confusión entre nulidad de pleno derecho y anulabilidad y la necesidad de la nulidad textual, el concepto de inexistencia pierde su función primitiva: retórica, clarificadora y de huida de la rigidez de la textualidad ${ }^{57}$.

La doctrina considera que las consecuencias de la inexistencia van a coincidir siempre con las de la nulidad radical o absoluta. Sin embargo, creemos que no va a ser así totalmente. La ineficacia que provenga de la inexistencia no va a ser igual a la que pueda derivar de contravenir una norma, pues en el caso de la primera (la inexistencia) los contratantes va a poder completar el contrato superando la ineficacia inicial ${ }^{58}$, y el segundo caso, no.

En la actualidad, la mayoría de nuestra doctrina aboga por considerar obsoleta dicha figura y su supresión ${ }^{59}$. En cuanto quedan definidas y distinguidas las categorías de la nulidad, consideran que deja de tener sentido utilizar la figura de la inexistencia ${ }^{60}$.

${ }^{55}$ Delgado Echeverría (n. 2), p. 239 y ss.; Puig Brutau (n. 36), p. 199 y ss. La doctrina más reciente, entre la que podemos citar a CASAdo CASAdo (n. 43), p. 3, parte de la distinción sólo de nulidad y anulabilidad -no de inexistencia- considerando que "un contrato es anulable cuando, reuniendo ése los requisitos esenciales para su existencia (art. 1261 del $C C$ ), posee algún vicio o falta de capacidad de obrar en alguna de las partes intervinientes. La parte que sufra dichos vicios, o dicha falta de capacidad, a tenor de los arts. 1263, 1265, 1266, 1267, 1268, 1269, 1270, 1301 y 1302 CC, estará legitimada para hacerla valer y proceder a declarar el contrato o acto realizado como anulable. En este sentido, la anulabilidad siempre es relativa, esto es, sólo determinadas personas pueden hacerla valer o están legitimados para alegarla".

${ }^{56}$ VÁzQuez de Castro (n. 4), p. 299.

${ }^{57}$ Op. cit., p. 329.

${ }^{58}$ Antonio Manuel Morales Moreno, "Comentario al artículo 1261 del Código civil”, en Cándido Paz-Ares Rodríguez, Luis Díez-Picazo y Ponce de León, Rodrigo Bercovitz Rodríguez-Cano y Pablo Salvador Coderch (dirs.), Comentario del Código civil, $2^{\text {a }}$ ed., Madrid, Editorial Ministerio de Justicia, Secretaría General Técnica, 1993, tomo II, p. 445.

${ }^{59}$ Así, entre otros, Manuel Miguel Traviesas, "Sobre nulidad jurídica", en Revista General de Legislación y Jurisprudencia, No 125 , Madrid, 1914, p. 491 y ss.

${ }^{60}$ VázQuez de Castro (n. 4), p. 330. 


\section{LA DELIMITACIÓN EXPRESA DE LOS SUPUESTOS DE INEXISTENCIA contractual en el Código CIVIL}

No es tarea fácil encontrar supuestos de inexistencia contractual. Nosotros partimos de la distinción entre inexistencia y nulidad. No obstante, no toda la doctrina científica realiza dicha diferencia, pues, aunque reconoce que diferenciarlas tiene un alcance práctico respecto a las consecuencias, pero considera a la inexistencia no como una categoría dogmática distinta de la nulidad, sino un simple instrumento dialéctico, que tendría utilidad para forzar los límites de una regulación sobre la nulidad ${ }^{61}$.

En la práctica, la jurisprudencia no ha distinguido estos supuestos de los de nulidad radical, pero sí que ha hecho mención en alguna ocasión sobre esa necesidad de distinguir entre inexistencia y nulidad, como hemos tenido ocasión de exponer en los puntos anteriores.

Cuando nos referimos a los supuestos de inexistencia derivada de la falta de alguno de los requisitos esenciales para celebrar un contrato (art. 1261 del Código Civil), la doctrina ha mantenido esta opinión, pero se ha mostrado discordante en cuanto a la admisión de la ausencia de causa. Se mantiene la aceptación de la inexistencia cuando se produce una falta absoluta de voluntad y de objeto, pero no cuando falta la causa ${ }^{62}$.

No estamos de acuerdo con esta postura porque es evidente que cuando falta un requisito esencial del contrato de los que menciona el art. 1261 del Código Civil (objeto y voluntad) normalmente coincide con la falta de causa y la consecuencia sería la nulidad estructural. Pero una cosa muy distinta es que ese elemento (la causa) al mismo tiempo sea utilizado como medio de fiscalizar la ilicitud, pero también lo puede ser el objeto. La consideración de la forma como requisito esencial del contrato es más discutible (como veremos más adelante), pero puede caber como requisito específico del tipo contractual, si bien, como indica la doctrina, en estos casos se podría considerar la falta de forma como una ilegalidad ${ }^{63}$.

${ }^{61}$ Delgado Echeverría y Parra Lucán (n. 51), p. 44.

${ }^{62}$ Susana Quicios Molina, "La ineficacia contractual", en Rodrigo Bercovitz RodríGuez-Cano (dir.), Nieves Moralejo Imbernón y Susana Quicios Molina (coords.), Tratado de Contratos, Concepto, límites, significación, requisitos, formación, forma, documentación, interpretación e integración, eficacia e ineficacia del contrato, Valencia, Tirant lo Blanch, 2009, tomo I, p. 1217, indica: "de lo dicho por los autores sobre este espinoso tema de la inexistencia contractual, cabría quedarse con estas dos consideraciones, Primera: la pugna más relevante enfrente a los que identifican inexistencia con nulidad absoluta, abogando por la intrascendencia de la primera, y a los que distinguen la inexistencia, como supuesto de hecho, de la consecuencia jurídica de tal supuesto, que puede ser la nulidad absoluta, la anulabilidad o incluso la eficacia (dependiendo del caso). Segunda: en puridad, sólo cabría hablar de inexistencia del contrato cuando no se ha realizado (no se ha perfeccionado), careciendo de apariencia jurídica".

${ }^{63}$ VÁzQuez de Castro (n. 4), p. 343. 
El sector defensor de su distinción ${ }^{64}$ y que seguimos en nuestra exposición consideró que los contratos inexistentes englobaban tres tipos:

a) Los incompletos, que incluían los supuestos de los contratos en formación, los realizados por quien no carece de poder suficiente para contratar y los que no respetan la forma ad solemnitatem requerida.

b) Los defectuosos o que carecen de algún elemento esencial.

c) Los aparentes o absolutamente simulados.

\section{Falta de requisitos esenciales del contrato}

\section{a) Ausencia de consentimiento}

El primero de los requisitos que enumera el art. 1261 del Código Civil es el consentimiento de los contratantes. La doctrina en este punto ha considerado que la falta de voluntad o consentimiento va a tener muy poca relevancia porque el consentimiento siempre irá referido a alguno al objeto y a la causa, pero nunca se puede considerar el consentimiento en abstracto.

Los supuestos en los que nos podemos encontrar que falte el requisito del consentimiento son los siguientes:

a) Cuando se produce una falta absoluta de voluntad o acuerdo de voluntades. Serían los casos en los que los cónyuges dijeran "no" en vez de "sí" cuando expresaron el consentimiento para la celebración del matrimonio. En los casos de simulación absoluta, fuerza absoluta, error absoluto, manifestación de voluntad animus ludi, falta de concurrencia entre la oferta y la aceptación.

${ }^{64}$ En contra, Quicios Molina (n. 64), p. 1217, al indicar: "Nos parece que inexistencia y nulidad absoluta no son términos alternativos, referidos ambos a sendos regímenes de ineficacia, sino que la inexistencia del contrato puede ser la causa de que se aplique el régimen de la nulidad absoluta (como puede ser la causa de que se aplique otro régimen de ineficacia, dependiendo de qué supuestos contractuales entendemos englobados en el término 'inexistencia'). Como no son términos incompatibles, aunque tampoco sea dable confundirlos, el Tribunal Supremo no tiene inconveniente en declarar, por ejemplo, que el contrato con causa falsa es inexistente o nulo. Si la inexistencia fuera, como creemos, un determinado supuesto de hecho, parece en todo caso que resulta un concepto inútil para descubrir lo que verdaderamente importa, esto es, el régimen jurídico anudado a tal supuesto de hecho. No tiene sentido crear un cajón más en el que introducir categorías ya conocidas (como a simulación, el error obstativo, el contrato celebrado por un falso representante), si esa creación no sirve para salvar las dudas que se tienen sobre la sanción aplicable a tales situaciones y tenemos después que separar las prendas en función del régimen de ineficacia aplicable. Por otra parte, la falta de apariencia del contrato, que es desde luego el supuesto indiscutido de inexistencia, no necesita un especial régimen jurídico, o bien porque no habrá tenido ningún efecto que deba deshacerse o bien porque no son imaginables otros regímenes distintos a los que ya se tienen". 
b) Cuando se arranca el consentimiento mediante una fuerza irresistible.

Respecto a este último supuesto, existe divergencias en la doctrina. Un primer sector considera que es habitual que se den vicios en el consentimiento que provoquen la anulación o anulabilidad del contrato por aplicación de los arts. 1263, 1265 y 1301 del Código Civil, pero no son supuestos de inexistencia.

El vicio en el consentimiento será siempre motivo de anulabilidad (art. 1301 del Código Civil) con lo que se le está concediendo suficiente protección jurídica, ya que es una acción con restricciones en cuanto a los legitimados para favorecer a quien ha sufrido el vicio ${ }^{65}$. No es preciso, por tanto, según esta postura, distinguir la violencia, como fuerza irresistible, para considerar que el consentimiento emitido de esta forma dé lugar a un contrato inexistente.

En los casos de que se emita una declaración de voluntad por quien no tiene discernimiento por ser menor de edad o por causa de una incapacidad mental, se aplicaría la misma solución.

Para esta postura, la total y exclusiva ausencia de voluntad que produzca la inexistencia es muy poco probable que se produzca.

Los supuestos de violencia absoluta y el contrato celebrado bajo la misma se consideran anulables, pero no inexistentes ${ }^{66}$.

Una segunda postura, de la que participamos ampliamente, considera que los supuestos en los que se emite el consentimiento mediando una fuerza irresistible son inexistentes.

Encuentra apoyo en algunas sentencias del Tribunal Supremo en las que ha aplicado -según la anterior postura, de forma poco rigurosa-, la falta de consentimiento como supuesto de inexistencia. Vamos a analizarlas con detención.

El primer caso lo encontramos en la sentencia del Tribunal Supremo de 21 de marzo de $1952^{67}$. Se trataba de un vendedor y prestatario que padecía una enfermedad (demencia senil) que le privaba de la aptitud síquica que se exige en el comercio jurídico, y no podía prestar el consentimiento conforme establece el art. 1262.2 del Código Civil. Se solicitaba en la demanda que se declarase que eran inexistentes los contratos de compraventa y préstamo, que éstos eran nulos por haberse celebrado para privar de legítima a los descendientes y que dichos bienes que habían sido objeto de los indicados contratos tenían que ser restituidos a la masa hereditaria del vendedor otorgante.

${ }^{65}$ VÁzQuez de Castro (n. 4), p. 345.

${ }^{66}$ Así, Antonio Gordillo CaÑas, "Violencia viciante, violencia absoluta e inexistencia contractual", en Revista de Derecho Privado, vol. 67, Madrid, marzo 1983, p. 252 y ss.

${ }^{67}$ R.A., Valencia, Thomson Reuters-Aranzadi, 1952, No 504. 
El juez de $1^{\mathrm{a}}$ instancia dictó sentencia declarando nulas y sin efecto ni valor el contrato de reconocimiento de deuda y los de compraventa de las fincas, ordenando la cancelación de las inscripciones motivadas por las referidas escrituras, y condenando al demandado a que devolviera la herencia, los bienes objeto de los contratos indicados, con los frutos percibidos desde la celebración. Apelada la anterior sentencia fue confirmada por la Audiencia Territorial.

Se interpuso recurso de casación por infracción de ley.

El Tribunal Supremo consideró que el contrato era inexistente por carecer del primero de los requisitos esenciales exigidos por el art. 1261 del Código Civil para que pudiera nacer el vínculo obligacional.

"Que por propia apreciación y también por aceptación de la del Juez de Primera Instancia, la Sala sentenciadora declaró probado que en el momento de la celebración de los contratos de compraventa y préstamo puestos en litigio, el vendedor y prestatario padecía demencia senil que le privaba de la aptitud psíquica que como mínimum se exige en el comercio jurídico, y, en consecuencia, no pudiendo prestar consentimiento dicho otorgante a tenor de lo dispuesto en el artículo 1263, número $2^{\circ}$ del Código Civil, los referidos contratos son nulos, con nulidad radical o inexistentes, por carencia del primero de los requisitos esenciales exigidos por el artículo 1261 del mismo Código para el nacimiento del vínculo jurídico obligacional.

Que, en impugnación de la referida tesis de la sentencia recurrida, denuncia el segundo motivo del recurso error de hecho y de derecho en la apreciación de las pruebas al deducir la Sala de instancia el estado de demencia, en el momento del contrato del hecho de que el otorgante fuese con anterioridad enfermo mental, sin que entre uno y otro hecho exista el enlace preciso y directo que prescribe el artículo 1253 del Código civil, máxime siendo presumibles la capacidad y la sanidad mental, y existiendo además declaración notarial afirmativa de la capacidad, todo ello sólo contradicho por el informe pericial del médico forense; pero a esta alegación del recurrente hay que oponer para desestimarla: Primero. Que el Tribunal 'a quo' no establece la deducción que se le atribuye, sino que se limita a aceptar, la que le ofreció el dictamen pericial en el sentido de que en demencia senil no hay período de reintegración psíquica, apreciando dicho dictamen en la forma prudencial prevista por el artículo 632 de la Ley de Enjuiciamiento civil; sin posibilidad de que tal apreciación por sí sola pueda ser revisada en este recurso extraordinario. Segundo: Que 
el tema de conexión entre el hecho demostrado y el deducido, a que se refiere el artículo 1253 del Código civil, no es propiamente cuestión de hecho, sino de juicio o raciocinio que el juzgador de instancia forma con arreglo a las normas abstractas del criterio humano, sólo censurables en casación si se demuestra que es ilógico, absurdo e inverosímil, y esta demostración ni se intenta siquiera en el recurso, y Tercero: Que, en cuanto al error de hecho denunciado, ni se precisa en qué consiste, aunque parece referirlo el recurrente a la declarada situación de demencia en el acto de contratar, ni se aduce acto o documento auténtico que acredite el error, ya que no se aprecia la ilación que pueda existir entre la diligencia de autopsia y otras actuaciones sumariales sobre causa terminante posterior del suicidio del aludido contratante, citadas por el recurrente, y el hecho de que anteriormente fuese enfermo mental e incapacitado para contratar la compraventa y el préstamo.

Que ante el hecho de que el Notario autorizante de la compraventa y el préstamo haya afirmado que el vendedor y prestatario tenía a su juicio capacidad para contratar, arguye el primer motivo del recurso que a tal afirmación hay que atenerse, como amparada por la fe pública, mientras no se demuestre o se declare la falsedad del documento notarial, pero este criterio tampoco se puede aceptar, porque la fe pública ampara la creencia del fedatario de que el otorgante es capaz, pero no la realidad de que lo sea, por tratarse de una apreciación psíquica y no de un hecho que se exteriorice siempre por signos perceptibles por el jurista, pues para constatar la veracidad en estos casos suelen ser precisos conocimientos científicos propios del psiquiatra, y así, tanto por lo dispuesto en el artículo 167 del Reglamento notarial (Rep. Leg. 994 y Diccionario 13983), como en el 1218 del Código civil, la afirmación por el fedatario de que a su juicio es capaz el compareciente ante él, constituye mera presunción "juris tantum" de exactitud, que los Tribunales pueden y deben revisar mediante prueba suficiente en contrario, y no hay duda que a este efecto es prueba adecuada en materia de enfermedades mentales el dictamen facultativo de personas especializadas en su diagnóstico y sus derivaciones.

Que en el tercero y último motivo del recurso se acumulan diferentes causas de impugnación de la sentencia recurrida por contradicción e incongruencia en el fallo y por error de derecho en la apreciación de las pruebas, y son desestimables todas las infracciones alegadas: Primero, porque no se aprecia incongruencia en el fallo recurrido que acoge casi literalmente lo pedido en la demanda; Segundo, porque el hecho de que el fallo declare la 
inexistencia de la compraventa y la nulidad del préstamo no implica contradicción alguna, ya que relacionando el fallo con sus fundamentos jurídicos claramente se aprecia que la falta de capacidad del vendedor y prestatario es la determinante de la nulidad de la compraventa y del préstamo, ambos inexistentes ante el derecho, y a esta inexistencia o nulidad absoluta es a la que se refieren los dos pronunciamientos del fallo; y Tercero, porque ya queda dicho que la sentencia recurrida no contiene el error de derecho en la apreciación de las pruebas que también en dicho motivo se denuncia”.

Con esta sentencia del Tribunal Supremo surgen las dudas respecto a otros supuestos que están relacionados. Si el Tribunal Supremo considera que la prestación del consentimiento que pueda emitir una persona con demencia senil no puede ser admitida, y el contrato es inexistente. Entonces, nos preguntamos, ¿qué sucede si presta ese "consentimiento" un menor no emancipado o un incapacitado. Conforme al art. 1263 del Código Civil no pueden prestar consentimiento. Pero el Código Civil protege a esos contratos en los que pudiera prestar el consentimiento esas personas no con la inexistencia sino con la anulabilidad (arts. 1301, 1302 y 1304 del Código Civil). Ahora bien, el propio art. 1300 del Código Civil indica que tiene que ser un contrato en que concurran los requisitos del art. 1261 del Código Civil. Si presta el consentimiento un menor no emancipado o un incapacitado, el instrumento no va a tener esos requisitos, ya que precisamente como no pueden prestar consentimiento, entonces si le falta un requisito (el consentimiento), ese contrato va a ser inexistente ${ }^{68}$.

Consideramos que existe una incongruencia en el Código Civil en ese punto. Aunque se establezca la anulabilidad por aplicación de los preceptos que hemos mencionado, lo más correcto sería considerarlos inexistentes porque falta el consentimiento y nos apoyaríamos en el propio art. 1261 del Código Civily en el art. 1263 del mismo texto legal, con lo que faltaría un requisito esencial en la celebración del contrato. Consecuencia de ello sería su inexistencia por falta de consentimiento.

En los casos de consentimiento prestado iocandi causa es interesante mencionar la sentencia del Tribunal Supremo de 24 de julio de $1989^{69}$. Son supuestos de declaraciones con falta de seriedad y de simulación absoluta. Se trataba de una reclamación del pago del premio de una participación de lotería comprada al demandado con anterioridad, que resultó agraciada, quedando el décimo en poder del demandado, que negó la venta de tal participación y su firma en el documento privado del demandado. Ambas

\footnotetext{
${ }^{68}$ También lo considera así García Amigo (n. 2), p. 400.

${ }^{69} R A$., Valencia, Thomson Reuters-Aranzadi, 1989, No 5776.
} 
partes habían estado enseñándose una serie de papeletas con cómics y chistes, algunos de las cuales simulaban recibos de lotería, rifas inexistentes y otros documentos, al mismo tiempo que rellenaban y firmaban algunos de manera alegre, pero sin intención alguna de que tuvieran validez aquellas bromas que se estaban gastando mutuamente. El demandante se quedó con algún documento de lo que habían escrito en tono jocoso, pero se trataba de una declaración iocandi causa.

El juzgado desestimó la demanda, sobre la base de la negativa del demandado y el resultado de la prueba pericial caligráfica, por no aclararse debidamente que fuese la misma firma, aunque consideró que parecía existir mayor similitud entre la firma de la participación y la firma puesta por el demandado al ser emplazado. La audiencia revocó la sentencia y estimó la pretensión.

Contra esta sentencia se interpuso recurso de casación sobre la base del art. 1692.5, Ley de Enjuiciamiento Civil, por entender el recurrente que al concederse fuerza probatoria al documento presentado para fundamentar la reclamación se contradecían los preceptos del ordenamiento jurídico establecedores de los principios dispositivos y de aportación de parte, infringiéndose el art. 1214 del Código Civil y que el juzgador de instancia había desconocido las reglas del mismo sobre atribución a cada parte de la carga de la prueba invirtiendo el onus probandi.

El Tribunal Supremo consideró:

"el consentimiento manifestado en forma jocosa no vicia su existencia, ni la del objeto y la causa, cuando éstos resultan claros de aquella expresión y no cabe dudar de su validez, es decir, que el consentimiento 'iocandi causa' sólo revela la inexistencia del contrato cuando de él se desprenden la falta de objeto cierto que sea materia del mismo o la falta de causa de la obligación que se establezca, nada de lo cual se da en el presente caso, en el que el buen humor en la forma, como muestra de alegría y complacencia e incluso de la duda o esperanza sobre la buena suerte que haya de acompañar a los contratantes en el juego de la lotería, en nada empece a la seriedad del contrato".

En la sentencia del Tribunal Supremo de 11 de marzo de $1988^{70}$ para argumentar la congruencia de su pronunciamiento dice:

${ }^{70}$ Id Cendoj: 28079110011988100183. Se puede acceder en: www.poderjudicial.es/search/ doAction?action $=$ contentpdf\&databasematch $=$ TS\&reference $=1169260 \&$ links $=$ falsa $\% 20 \mathrm{o} \% 20$ simulada\&optimize $=20051011$ \&publicinterface $=$ true. Consultada el 16 de agosto de 2012. 
"son los mismos los hechos que destituyen de efectos a la causa de la adquisición de la nuda propiedad, sea su inexistencia o ser falsa o simulada, diferentes versiones verbales de lo alegado que es no haberse llegado a consentir sobre las prestaciones que había de asumir el demandado".

Encontramos un supuesto en el que no se acuerda el concurso o acuerdo de la oferta y la aceptación a que se refería el art. 1262 del Código Civil y no existe consentimiento en la sentencia del Tribunal Supremo de 8 de julio de $1987^{71}$ que consideró que el contrato de arrendamiento no había nacido, es decir, no existirá, ya que:

"nunca se alcanzó el acuerdo o concurso de la oferta, de una parte y la aceptación de la otra, que refiere el artículo mil doscientos sesenta y dos del Código Civil como manifestación del consentimiento ni siquiera verbal, imprescindible, conforme al artículo mil doscientos sesenta y uno, para que pudiera haber nacido el tal contrato de arrendamiento".

b) Ausencia de objeto.

El art. 1271 del Código Civil nos indica:

"pueden ser objeto de contrato todas las cosas que no están fuera del comercio de los hombres, aun las futuras.

Sobre la herencia futura no se podrá, sin embargo, celebrar otros contratos que aquellos cuyo objeto sea practicar entre vivos la división de un caudal conforme al artículo 1056.

Pueden ser igualmente objeto de contrato todos los servicios que no sean contrarios a las leyes o a las buenas costumbres".

Este precepto no nos habla de los contratos sin objeto, sino de lo que no puede ser objeto del mismo: res extracomercium, servicios que sean contrarios a las leyes o a las buenas costumbres.

Cuando nos vamos a encontrar con supuestos de inexistencia porque falte el objeto contractual van a ser aquéllos en los que no esté determinado suficientemente. No hay que olvidar que el art. 1273 del Código Civil

${ }^{71}$ Id Cendoj: 28079110011987100094. Se puede acceder en: www.poderjudicial.es/search/ doAction?action $=$ contentpdf $\&$ databasematch $=T S \&$ reference $=1168286 \&$ links $=$ nunca $\% 20$ se $\% 20$ alcanz $\%$ F3 $\% 20$ el $\% 20$ acuerdo $\% 20$ o $\% 20$ concurso $\% 20 \mathrm{de} \% 201 \mathrm{a} \% 20$ oferta\&optimize $=20051011 \&$ publicinterface $=$ true. Consultada el 16 de agosto de 2012 . 
dispone que el objeto de todo contrato debe ser una cosa determinada en cuanto a su especie y que la indeterminación en la cantidad no será un obstáculo para la existencia del mismo, siempre que sea posible determinar dicha cantidad sin necesidad de un nuevo convenio entre las partes, y que el art. 1272 del Código Civil indica que no pueden ser objeto de un contrato las cosas o servicios imposibles.

Conforme a estos preceptos, los supuestos en los que no existirá un objeto contractual serán:

a) Aquéllos en los que no esté determinado suficientemente dicho objeto en cuanto a la especie a la que pertenezca.

b) Los supuestos en los que exista una indeterminación en la cantidad y para determinarla sea preciso un nuevo convenio entre los contratantes.

c) En los casos en los que el objeto es un imposible (cosa o servicio) y no se puede realizar.

d) Cuando hay identidad de sexos en el matrimonio.

e) La adopción como hermano en vez de como hijo.

f) La entrega de una cosa no vendida.

g) El pago de lo indebido.

Suele suceder que en los casos en los que falta es la realidad del precio en los contratos de compraventa se suele considerar que lo que se produce es una simulación por causa falsa y no una inexistencia de objeto. No estamos totalmente de acuerdo, ya que la falta de un precio se podría incluir como un concepto amplio de objeto, en el sentido de contenido prestacional.

No es frecuente encontrar sentencias en las que falte el requisito del objeto. Son supuestos en los que desde la perspectiva del consentimiento se analizan el objeto y la causa en el plano de la realidad. En la mayoría de ocasiones sólo tiene explicación porque se celebre un contrato sin objeto o carente de causa porque exista simulación o error ${ }^{72}$.

Resulta destacable la sentencia del Tribunal Supremo de 22 de marzo de 1924 en la que se indicó: "la falta de objeto daría lugar a la inexistencia del contrato, no a su nulidad o invalidación". Esta misma sentencia aceptó como válida la

“acción de nulidad por inexistencia, la que se ejercitó con base en una simulación absoluta por falta de los requisitos indispensables para la realidad del contrato".

\footnotetext{
${ }^{72}$ VázQuez de Castro (n. 4), p. 344.
} 
La jurisprudencia se ha inclinado a considerar estos supuestos como una simulación antes de considerarlo como falta de objeto. Así, la sentencia del Tribunal Supremo de 29 de abril de $1997^{73}$ entendió que:

“el plazo 'sanatorio' de cuatro años del artículo 1301 del Código Civil, es aplicable solamente a los contratos 'en que concurran los requisitos del artículo 1261' (artículo 1300 del Código Civil). Es un plazo aplicable a los llamados contratos anulables. Los contratos afectos de nulidad absoluta, radicalmente nulos, inexistentes en derecho, no pueden convalidarse por el transcurso del tiempo. La acción de nulidad es imprescriptible. Los efectos de la sentencia que la estima son declarativos, no constitutivos, 'ex tunc', no 'ex nunc'. 'La nulidad propiamente dicha, absoluta o de pleno derecho, tiene lugar cuando el contrato es contrario a las normas imperativas y a las prohibitivas o cuando no tiene existencia por carecer de alguno de sus elementos esenciales, como sucede en el caso del contrato, pues según el artículo 1261 del Código Civil no existe si falta el consentimiento, el objeto o la causa; y al faltar aquí esta última, la consecuencia ineludible es la del artículo 1265, estando al margen de posibilidad sanatoria y de todo plazo prescriptito, justo por ser la expresión del nada jurídico, que siempre y en todo momento puede ser alegad' (sentencia de 13 febrero 1985 [RJ 1985/810]). 'El artículo 1300 del Código Civil sólo es aplicable a los supuestos en que existe verdadero contrato por reunir los requisitos del artículo 1261 del Código Civil, pero no cuando por simulación absoluta hay inexistencia de causa y total privación de efectos contractuales según el artículo 1275 del Código Civil' (sentencia de 5 noviembre 1981 [RJ 1981/4420]). En idéntico sentido se pronuncia la sentencia de 23 julio 1993 (RJ 1993/6475)".

c) Ausencia de causa.

Referencia a los artículos 1275 y 1277 del Código Civil

Nos detendremos en los casos de simulación absoluta. Cuando nos referimos a ellos habrá referencia a la causa del contrato. El hallazgo de supuesto que sean de simulación absoluta es bastante difícil, porque en estos supuestos lo más habitual es que los contratantes que han procedido con la simulación suelan pretender realizar un negocio jurídico diferente al aparente (simulación relativa) y no carecen absolutamente de causa ${ }^{74}$.

${ }^{73}$ Id Cendoj: 28079110011997101515. Se puede acceder en: www.poderjudicial.es/ search/doAction?action $=$ contentpdf\&databasematch $=$ TS\&reference $=2339257 \&$ links $=\mathrm{s}$ anatorio\&optimize $=20040521 \&$ publicinterface $=$ true. Consultada el 16 de agosto de 2012.

${ }^{74}$ Vázquez de Castro (n. 4), p. 343. 
La simulación relativa tiene como singularidad que encubre un convenio con inexistencia real, otro con realidad causal subyacente. En estos casos de simulación relativa, no existe el contrato que se aparenta (no existe causa, no existe, por tanto, contrato según el art. 1261 del Código Civil). Sólo existe el que se encubre. Es frecuente hallar sentencias que aplican el art. 1276 del Código Civil y analizan la validez y licitud del contrato simulado subyacente para ver si origina efectos.

Es habitual encontrar supuestos en los que las compraventas encubren donaciones al no haber sino declaración simulada de entrega del precio o ser el mismo ridículo o irrisorio. En estos supuestos si la donación encubierta lo es de bienes inmuebles y no se ha observado la forma legalmente exigida en el art. 633 del Código Civil, ésta se ha de considerar nula de pleno derecho por defecto de forma.

Más difícil resulta poder encontrar sentencias que aludan al art. 1275 del Código Civily sean supuestos en los que se dé una simulación absoluta o falta de causa. El contrato simulado es inexistente por falta de causa; sin embargo, aquél con causa ilícita no es contrato inexistente.

Sobre esta cuestión la sentencia del Tribunal Supremo de 27 de diciembre de 1966 declaró:

"si bien es cierto (...) que es improcedente la aplicación del art. 1261 del C.c., que se refiere estrictamente y a sensu contrario a los contratos que por falta alguno de los requisitos que enumera carecen de vida en derecho, lo que aquí no sucede (...), porque una cosa es que no exista una causa y otra distinta que ésta sea ilícita (...); y si consiguientemente deben diferenciarse como dos acciones distintas, de un lado, la de simulación que trata de demostrar la falsa apariencia de un contrato que carece de toda existencia real, $\mathrm{y}$, de otro, la de nulidad basada en la ilicitud, que parte de la base de la realidad de un pacto, uno de cuyos elementos -concretamente la causa para este caso- existe, pero es ilícito, calificación que forzosamente tiene que apoyarse en la existencia de aquélla”.

En alguna sentencia del Tribunal Supremo encontramos una total identificación de los efectos de la inexistencia con los de la nulidad radical o de pleno derecho. Así, la sentencia del Tribunal Supremo de 21 de octubre de $1997^{75}$ en el que se resolvió un supuesto de simulación absoluta

${ }^{75}$ Id Cendoj: 28079110011997102099. Se puede acceder en: www.poderjudicial.es/ search/doAction?action $=$ contentpdf $\&$ databasematch $=$ TS\&reference $=3239207 \&$ links $=\mathrm{s}$ imulaci $\% \mathrm{~F} 3 \mathrm{n} \% 20$ profusamente\&optimize $=20030704 \&$ publicinterface $=$ true. Consultada el 16 de agosto de 2012. 
que, aunque creaba una apariencia negocial, carece de causa. Su falta produce la inexistencia:

"La base jurídica se halla en el tema de la simulación profusamente tratado por la doctrina y reiteradamente por la jurisprudencia, con la normativa que se deriva de los arts. 1275 y 1261.3 del Código Civil. Con la simulación no se crea sino una mera apariencia negocial (sentencias de 5 de marzo de 1987 [RJ 1987/1415], 23 de octubre de 1992 [RJ 1992/8279]), el negocio jurídico carece de causa (sentencias de 30 de octubre de 1985 [RJ 1985/5133], 24 de febrero de 1986 [RJ 1986/935], 29 de septiembre de 1988 [RJ 1988/6933], 29 de noviembre de 1989 [RJ 1989/7921], 1 de octubre de 1990 [RJ 1990/7462], 1 de octubre 1991 de [RJ 1991/7438], 23 de octubre de 1992 [RJ 1992/ 8279], 17 de mayo de 1993 [RJ 1993/3554], 29 de julio de 1993 [RJ 1993/6493], 16 de marzo de 1994 [RJ 1994/1984], 15 de marzo de 1995 [RJ 1995/2656] y 25 de mayo de 1995 [RJ 1995/4265]), por lo que adolece de la falta del elemento esencial del negocio jurídico, que se expresa el número $3^{\circ}$ del artículo 1261 del Código Civil, con la consecuencia de que es inexistente (sentencias de 16 de abril de 1986 [RJ 1986/1854], 29 de noviembre de 1989, 3 de febrero de 1993 [RJ 1993/801], 23 de mayo de 1994 y 25 de mayo de 1995); el negocio jurídico simulado cae, pues, en la categoría de la inexistencia, si bien, a veces, en la doctrina se han fundido los conceptos de nulidad e inexistencia y en la jurisprudencia se ha empleado la expresión nulidad o nulidad absoluta o nulidad radical para referirse al negocio inexistente por falta de causa en los casos de simulación absoluta, como ocurre en la propia sentencia impugnada (sentencias de 5 de marzo de 1987, 1 de octubre de 1990, 24 de octubre de 1992 [RJ 1992/8282], 23 de julio de 1993 [RJ 1993/6475], 7 de febrero de 1994 [RJ 1994/918] y 6 de octubre de 1994 [RJ 1994/7459]).

Este ha sido el caso presente. Tal como ha declarado la sentencia de instancia, se ha producido una apariencia de negocio jurídico de compraventa, en la que el vendedor carecía de título, continuó la posesión de la cosa vendida y se da una absoluta ausencia de prueba acreditativa del pago del precio. Casos semejantes a éste han sido frecuentemente tratados por esta Sala en el mismo sentido de declarar la inexistencia de tal compraventa: sentencias de 5 de marzo de 1987, 29 de septiembre de 1988, 1 de octubre de 1990, 1 de octubre de 1991, 16 de marzo de 1994, 15 de marzo de 1995, 10 de diciembre de 1995 y 14 de abril de 1997 (RJ 1997/2882). La de 26 de marzo de 1997 (RJ 1997/1996) resume: La simula- 
ción absoluta da lugar a un negocio jurídico que carece de causa; oculta, para la apariencia de un negocio jurídico como puede ser la compraventa, un caso de inexistencia del mismo por falta de causa. El negocio simulado es inexistente por falta de causa, por aplicación del artículo 1275 del Código civil en relación con el 1261, número $3^{\circ}$, aunque hay que tener en cuenta la presunción de causa del artículo 1277. Este es el caso de la compraventa en que no ha habido precio.

Analizando los motivos de casación admitidos, todos ellos fundados en el número $4^{\circ}$ del artículo 1692 de la Ley de Enjuiciamiento Civil, el cuarto alega infracción del artículo 205 de la Ley Hipotecaria (RCL 1946/342 y NDL 18732), lo que no tiene sentido pues esta norma prevé el medio de acceso en el Registro de la Propiedad de títulos públicos sobre finca no inmatriculada, de adquisición de dominio, anterior en más de un año, con publicación de edictos y cuya inmatriculación no surte efectos respecto de terceros hasta transcurridos dos años; ni la sentencia impugnada ha hecho aplicación de este artículo, ni el recurso de casación indica en qué ha sido infringido, ya que simplemente narra una particular versión de los hechos; alega asimismo infracción del artículo 34 de la Ley Hipotecaria, protección al tercero hipotecario, adquirente de buena fe, a título oneroso, del titular registral, que inscribe su derecho, que tampoco tiene aplicación al caso de autos ni se indica en qué ha sido infringido.

El motivo quinto alega -literalmente- 'infracción de norma relacionadas con el pago del precio', explica una vez más unos hechos acordes con su versión subjetiva de los mismos, insiste en la realidad del precio, que la sentencia impugnada considera inexistente y termina, sorprendentemente, afirmando que aunque el precio no se hubiera pagado, el pago no es requisito imprescindible para la perfección del contrato y alega infracción del artículo 1450 del Código Civil. El motivo carece de la más mínima base jurídica, no parece entender la argumentación de la sentencia ni la normativa que ha aplicado: declara acreditada la inexistencia (no la falta de pago) del precio y, en consecuencia, la falta de causa de la compraventa y la inexistencia de ésta. Explicar unos hechos distintos y alegar el artículo 1450 del Código Civil no tiene el más elemental sentido para sustentar un motivo de casación.

El motivo sexto alega infracción, por inaplicación, del art. 1462 del Código Civil y se refiere a la entrega de la posesión de la casa del codemandado señor $\mathrm{T}$. al otro codemandado señor L., recurrente en casación. Alega otros preceptos (art. 1254 y ss. y 1257 y 
1258 del Código Civil y 278 Compilación de Cataluña) y vuelve a una versión de los hechos, como si se tratara, no de una casación, sino de una primera instancia. Todos los hechos que se exponen y normas que se alegan en este motivo, no tienen sentido en cuanto se debe partir de que, según los hechos acreditados en la sentencia de instancia, la compraventa entre dichos codemandados nunca existió, por simulación absoluta".

La doctrina considera que en la jurisprudencia se utiliza la figura de la inexistencia para destacar que dentro de la categoría de la nulidad existen diferentes regímenes dependiendo del tipo de anomalía. Estas anomalías significan la dificultad de enunciar reglas generales y no indican que se deba entender que existan dos variedades distintas dentro de la especie nulidad $^{76}$.

Por su parte, la sentencia del Tribunal Supremo de 23 de diciembre de $1997^{77}$ en el que se contempló el caso de una donación realizada por el pródigo a favor del curador. Una persona había sido declarada pródiga mediante una sentencia del año 1978. Con posterioridad, se adaptó la declaración de prodigalidad al nuevo régimen instaurado por la ley 13/1983, de 24 de octubre, de reforma del Código Civil en materia de tutela, nombrándose curadora a su hija. En el año 1988, el pródigo realiza una donación de cuatro fincas a sus hijos, uno de ellos era la curadora. Mediante auto de 1990 se remueve a la anterior curadora y se nombra defensores judiciales, en tanto no se procediera a nombrar nuevo curador, del pródigo a sus otros dos hijos.

Estos últimos formulan demanda contra el pródigo y contra los donatarios ejerciendo acción de nulidad de la donación efectuada. El Juzgado de $1^{\text {a }}$ Instancia dictó sentencia que estimó parcialmente y declaró la nulidad de la donación a favor de la curadora y la desestimó respecto a la donación efectuada a los demás hijos. Se interpuso recurso de apelación por los demandantes y la Audiencia Provincial dictó sentencia en 1993 por la que se revocó la anterior y estimó la donación. Contra esta sentencia interpusieron los demandados recurso de casación.

El Tribunal Supremo declaró:

"Son fundamentos jurídicos básicos, necesarios para entrar en el tema que aquí se plantea-que no es otro que la validez de una

${ }^{76}$ VÁZQuez de Castro (n. 4), p. 330.

${ }^{77}$ Id Cendoj: 28079110011997101708. Se puede acceder en: www.poderjudicial. es/search/doAction?action=contentpdf\&databasematch $=$ TS\&reference $=23394$ $50 \&$ links $=$ la $\% 20$ validez $\% 20$ de $\% 20$ una $\% 20$ donaci $\%$ F 3 n $\% 20$ hecha $\% 20$ por $\% 20$ persona\&optimize $=20040521$ \&publicinterface $=$ true. Consultada el 21 de agosto de 2012. 
donación hecha por persona que ha sido declarada pródiga- los siguientes: el donante se hallaba, al tiempo de la donación, en el estado civil de prodigalidad; no se plantea, ni puede plantearse, cuestión alguna sobre ella, declarada por sentencia firme en 1978, que, tal como establece la disposición transitoria segunda de la Ley 13/1983, de 24 octubre, antes citada: las tutelas de los pródigos actualmente constituidas (como es el caso presente) se regirán en lo sucesivo por lo establecido en esta Ley para la curatela; no se plantea, ni puede plantearse, cuestión alguna sobre la legitimidad o sobre el derecho de alimentos, que podía ser la base, la primera, de la declaración de prodigalidad anterior a la Ley de 1983, o el segundo, de la actual, pero una vez declarada, ninguna trascendencia tiene respecto a la validez de un negocio jurídico de disposición de inmuebles a título gratuito, como es la donación.

El pródigo queda sujeto a la curatela (disposición transitoria citada y artículo $286.3^{\circ}$, Código Civil vigente) y no es un incapacitado total (como el que contempla el artículo 222, núm. 2 del Código Civil) sino que queda restringida su capacidad, como incapacitado parcial, en el sentido en que precisa el complemento de capacidad ('asistencia', 'intervención', 'consentimiento' según terminología del código) que le otorga el curador: la curatela no tendrá otro objeto que la intervención del curador en los actos que los pródigos no puedan realizar por sí solos (tal como dice el art. 288 Código Civil) y tales actos son los que haya determinado la sentencia (añade el artículo 298). La sentencia declarando la prodigalidad, como antes se ha transcrito, declara expresamente que le incapacita para disponer de sus bienes; añade que precisa la autorización previa del consejo de familia; desaparecido éste y aplicando la disposición transitoria segunda de la Ley de 1983 de que se ha hecho transcripción, actualmente es el curador; así, la sentencia determinó los actos que el pródigo no podía realizar por sí solo y, hoy, precisan para su validez el complemento de capacidad del curador, según los citados artículos 288 y 298; entre ellos recuenta la donación a que se refiere el presente proceso.

La invalidez de tales actos, hechos sin la autorización o intervención o consentimiento, es decir, sin el complemento de capacidad del curador, viene determinada por lo dispuesto en el artículo 293, en el sentido de que son anulables. Distinto es el caso del negocio de disposición a título gratuito a favor del curador, que cae bajo el imperio de la norma prohibitiva del artículo 221, número $1^{\mathrm{o}}$, referido a todo cargo tutelar, que es de nulidad absoluta 'ipso iure', como establece el artículo 6.3 del Código Civil. 
El primero de los motivos de casación alega inaplicación del artículo 1288 y aplicación errónea del artículo 1290 del Código Civil, pero en el desarrollo del motivo no se expone en qué consiste aquella inaplicación o esta aplicación errónea, ni se comprende en qué puedan consistir, ya que nada tienen que ver la regla contra 'proferentem' de la interpretación de los contratos (artículo 1288) ni la rescisión de los mismos (artículo 1290) al caso de autos.

En el desarrollo del motivo se menciona la inoficiosidad legitimaria y el derecho de alimentos, que tuvieron (la legítima) y tienen (el derecho de alimentos) importancia para la declaración de prodigalidad, pero carecen de ella en el tema aquí planteado, de la invalidez de una donación cuyo donante es una persona en estado civil de prodigalidad, sin el complemento de capacidad de la curadora y siendo ésta, para mayor ludibrio, una de las donatarias. Se menciona asimismo el artículo 298 del Código Civil que ya ha sido tratado anteriormente y que no alega aquí como infringido, motivo de casación. La Sentencia que cita, de 2 enero 1990 (RJ 1990/1) se refiere a un supuesto en que se denegó la declaración de prodigalidad y se declaró la nulidad por simulación de unas compraventas; por tanto, un tema radicalmente distinto al de autos.

El segundo motivo de casación alega infracción de los artículos $286.3^{\circ}, 298$ y 293 del Código Civil. El recurso de casación se formula contra el fallo de la sentencia recurrida, en base a los fundamentos en que se ha basado. En el desarrollo del motivo se expresan argumentos ciertos, otros desacertados y llega a la conclusión equivocada de que la donación objeto de la acción ejercitada es válida. Como se ha expuesto anteriormente, la donación es un negocio jurídico dispositivo a título gratuito y éste no podía ser realizado por el pródigo sin autorización del consejo de familia, según dispuso la sentencia firme del Tribunal Supremo; Desaparecido el consejo de familia, era el curador -según el Código Civil reformado por la Ley de 1983- quien debía dar el complemento de capacidad. Realizada la donación sin la autorización (complemento de capacidad) del curador, ésta es anulable. Realizada a favor de la propia curadora, es nula. Una vez declarada la anulación, consecuencia de la anulabilidad, queda anulado o nulo el negocio jurídico, es decir, la donación. La consecuencia, la nulidad, es la misma. Por tanto, el fallo de la sentencia es correcto, aunque no lo es la asimilación que hace al artículo 166 del Código Civil ni la afirmación de que esta norma impone la nulidad, ya que ciertamente la sanción es de anulabilidad, como declara la jurisprudencia más reciente: Sentencias de 2 junio 1989 (RJ 1989/4283) y 9 mayo 
1994 (RJ 1994/3894); esta última dice: la enajenación realizada sin la previa autorización judicial no es inexistente en el sentido del artículo 1261, ni nula en el del 6.3, sino que, como declaró la Sentencia de 9 diciembre 1953 (RJ 1954/284), puede la enajenación convalidarse al llegar el menor a la mayoría de edad, por lo que se inclina por la simple anulabilidad, criterio éste que está en línea con la doctrina declarada en las de fechas 29 noviembre 1958 (RJ 1958/3811) y 19 diciembre 1977 (RJ 1977/4763) e, incluso, la de 21 mayo 1984 (RJ 1984/2497), y aun cuando existen otras Sentencias, entre ellas, las de 9 diciembre 1953 (sin perjuicio de la convalidación por el menor al llegar a la mayoría de edad) y 25 junio 1959 (RJ 1959/2933), partidarias de la nulidad radical, procede reafirmar la naturaleza anulable de tales enajenaciones, toda vez que el matiz diferenciador que supera la anulabilidad de la nulidad es la calificación del interés, público o privado, a cuya protección se ordenan y así, la defensa del interés público exige la indisponibilidad de la ineficacia de los actos contrarios a dicho interés, mientras que cuando está en juego es el simple interés privado de los particulares.

El tercero de los motivos de casación alega infracción de los artículos 294, 6.4 y 7.1 del Código Civil. En cuanto al primero de estos artículos se confunde la declaración de prodigalidad, hecha por sentencia firme del Tribunal Supremo, con la invalidez de la donación otorgada por el pródigo, que es el objeto de la acción ejercitada en el presente proceso. En cuanto al segundo y al tercero, son cuestiones nuevas que no se acreditan, en ninguno de sus requisitos, en el presente caso, pues nos e puede pensar en un fraude de ley ni en ejercicio no conforme a las normas de la buena fe, respecto a una acción en que se pretende la nulidad y anulación de una donación hecha por persona declarada pródiga.

Se menciona también en este motivo -y también se apunta en el anterior- la legitimación activa de los demandantes, sin que se alegue como motivo de casación; la misma es indudable a la vista de que son defensores judiciales del pródigo, nombrados como tales mientras no se provea la constitución de una nueva curatela y con las funciones del curador (artículos 302 en relación con el 293).

En consecuencia, todos los motivos de casación deben ser desestimados, debe declararse no haber lugar al recurso e imponer las costas a la parte recurrente".

Es muy importante la acreditación de la inexistencia del precio porque resulta obligado desvirtuar la presunción de existencia de causa 
que establece el art. 1277 del Código Civit ${ }^{8}$. Así, lo podemos contemplar, entre otras, en la Sentencia del Tribunal Supremo de 19 de noviembre de $1990^{79}$ que declaró:

“...Que partiendo de las directrices doctrinales y judiciales respecto al concepto de causa de los contratos e, incluso, la conexión entre la misma y los motivos se puede verificar esta síntesis jurisprudencial: Como es sabido, a través del art. $1274 \mathrm{CC}$ se da un supuesto de inexistencia contractual -por falta de causa, STS 24-2-2986 (RJ 1986/850) - y que tal carencia proviene en razón al sentido de la causa inmerso en el art. 1275 del C.c. sobre lo que ha de advertirse, en línea de principio, que para entender el verdadero alcance o significado de la causa como razón de ser del contrato $-\mathrm{y}$ con una incesante polémica doctrinal respecto a su exacta configuración-, no puede omitirse el peso que en toda esa configuración debe ostentar la real intención o explicación del componente de voluntad que cada parte proyecta al consentir el negocio, y que si ésta puede explicitarse, en el conjunto de las circunstancias que emergen de la situación subyacente que origina el negocio que se lleva a cabo, ha de tenerse en cuenta la misma para integrar aquel concepto, pues de esa forma se consigue localizar un presupuesto de razonabilidad que funda el intercambio de prestaciones efectuado; bien es cierto que con ello se margina la dualidad entre la causa como elemento objetivo trascendente, con los móviles internos de cada interesado -es conocida esa distinción, expuesta entre otras muchas en la STS 30-12-1985(RJ 1985/6620) de que 'la causa se diferencia de los motivos en que se determina por los móviles con trascendencia jurídica, que incorporados a la declaración de voluntad en forma de condición o modo forman parte de aquélla a manera de motivo esencial impulsivo o determinante'-; mas, se repite, según la información que late en ese principio jurisprudencial, la conjunción entre ambos es posible, sobre todo, si la ser lícitos los móviles particulares que implícitamente explican el negocio en su respectiva repercusión interna para cada interesado, coadyuvan al hallazgo de aquel designio de razonabilidad, e, incluso, partiendo de la triple distinción de

${ }^{78}$ VÁZQuez de Castro (n. 4), p. 344, n. 142.

${ }^{79}$ Id Cendoj: 28079110011990100574. Se puede acceder en: www.poderjudicial. es/search/doAction?action $=$ contentpdf $\&$ databasematch $=$ TS\&reference $=1171362 \&$ lin $\mathrm{ks}=$ siendo $\% 20$ por $\% 20$ ello $\% 20$ il $\%$ EDcito $\% 20$ todo $\% 20 \mathrm{el} \% 20$ aparato $\% 20$ negocial $\% 20$ verificado\&optimize $=20051011 \&$ publicinterface $=$ true. Consultada el 21 de agosto de 2012 . 
la doctrina más decantada, entre la causa de la atribución, causa de la obligación y causa del contrato (el porqué el atributario está jurídicamente facultado para recibir el desplazamiento patrimonial, fuente constitutiva de la obligación, o fin común perseguido en el negocio por las partes, respectivamente) habría de adscribir ese juego de conjunción en el primer expediente de ese proceso, esto es, en la causa de la atribución.

...la recta hermenéutica que de la causa se regula en la sección $3^{\mathrm{a}}$. del Título II del Libro IV del C.c., arts. 1274 a 1277, en el bien entendido que así como en el 1274 al emitir un concepto legal de causa se hace constar que en los contratos onerosos, como sin lugar a dudas es el controvertido, se entenderá por causa para cada parte contratante la prestación o promesa de una cosa o servicio por la otra parte, que no es sino la finalidad socioeconómica que cada parte persiga al contratar, y que en los negocios de intercambio, implica, la recepción de objeto de la prestación o contraprestación de la otra parte en equivalencia a ala entrega o cumplimiento de la prestación comprometida por la misma; que en el 1275, se sanciona que los contratos sin causa o con causa ilícita no producen efecto alguno y, naturalmente, ello aduce a la diferencia, bien elemental, de que es muy distinto un contrato sin causa, esto es, donde ese presupuesto no consta ni aparece en los términos a que se refiere el art. 1262 y que, por lo tanto no hay mecanismo alguno para descubrir cuál es la razón de ser o la finalidad que persigue cada parte al contratar, con la otra eventualidad de la causa ilícita en que se tratará, en su caso, de un contrato en donde existiendo la causa ésta, por su singularidad o sus connotaciones, es contraria a las leyes o a la moral, siendo por ello ilícito todo el aparato negocial verificado; que en el art. 1276, asimismo, se sanciona que la expresión de una causa falsa, esto es, no real o verdadera, en principio provoca la nulidad del contrato, salvo que se acreditase que esa causa falta o aparencial encubriese otra real que, a su vez fuese lícita o conforme a las leyes y a la moral, y, por último, en el 1277 se establece el principio general de la existencia de la causa o que la presunción de su existencia ha de operar con el valor 'iuris tantum' en tanto en cuanto la parte perjudicada por ello, no pruebe lo contrario".

La jurisprudencia consiente que se pueda desvirtuar la presunción por diversos medios:

a) Los que enumera el art. 1215 del Código Civil.

b) A través de las manifestaciones de los interesados en sus escritos. 
En este sentido, la sentencia del Tribunal Supremo de 2 de febrero de $1984^{80}$ (R.A., 1984, 569) consideró:

"como esta Sala viene sancionando con reiteración -SS. de 6 de mayo de 1950 (RJ 1950\736), 14 de marzo de 1958 (RJ 1958\1080), 22 de febrero de 1963 (RJ 1963\827), 25 de junio de 1969 (RJ $1969 \backslash 3641)$ y la bien reciente de 20 de diciembre de 1983 (RJ 1983\6968)- ..., si bien es cierto que el art. 1277 del C. Civ. establece una presunción legal a favor de la existencia y licitud de la causa de los negocios jurídicos y exonera a los favorecidos por ella de la carga de la prueba, no lo es menos que admite la posibilidad de que se acredite lo contrario, cosa que puede llevarse a efecto por cualquiera de los medios que se enuncian en el 1215 e incluso a través de las manifestaciones de los interesados en sus respectivos escritos".

Del mismo modo, la sentencia del Tribunal Supremo de 25 de junio de $1979^{81}$ (R.A., 1979, 2909) indicó:

"al amparo del art. 1692, núm. 7. ${ }^{\circ}$, de la L.E. Civ., se alega por el Estado recurrente error de derecho en la apreciación de la prueba con violación del art. 1232 del C. Civ., motivo que es forzoso rechazar porque no basta aducir violación para sentar que a la prueba de confesión no se le haya dado el valor que se pretende en el recurso, ya que no hay norma que obligue al Juzgador a dar valor preferente a una prueba sobre otra -en este caso la de confesión ya no reina de la pruebas: SS. de 10 de marzo de 1966 (RJ 1966\1091), 7 de junio de 1968 (RJ 1968\3178) y 18 de noviembre de 1969 (RJ 1969 55287)- dado el principio de libre apreciación judicial vigente en nuestro sistema, pues la Sala de instancia, sin hacer una apreciación conjunta de la prueba, basó su decisión en la testifical, tan válida y eficaz como las demás, apreciándola de modo crítico al analizar sus matices personales y circunstanciales en relación con el parentesco lejano de vendedor y compradora, y obteniendo

${ }^{80}$ Id Cendoj: 28079110011984100310. Se puede acceder en: www.poderjudicial.es/ search $/$ doAction?action $=$ contentpdf\&databasematch $=$ TS\&reference $=4408069 \&$ links $=$ est ablece $\% 20$ una $\% 20$ presunci $\%$ F3n $\% 20$ legal $\% 20 \mathrm{a} \% 20$ favor $\% 20 \mathrm{de} \% 201 \mathrm{l} \% 20$ existencia $\% 20$ $\% 20$ licitud\&optimize $=19960113 \&$ publicinterface=true. Consultada el 21 de agosto de 2012.

${ }^{81}$ Id Cendoj: 28079110011979100440. Se puede acceder en: www.poderjudicial. es $/$ search $/$ doAction ?action $=$ contentpdf $\&$ databasematch $=$ TS\&reference $=4426548 \&$ lin $\mathrm{ks}=$ no $\% 20$ basta $\% 20$ aducir $\% 20$ violaci $\%$ F3n $\% 20$ para $\% 20$ sentar $\% 20$ que $\% 20 \mathrm{a} \% 201 \mathrm{a} \% 20$ prueba $\% 20 \mathrm{de} \% 20$ confesi $\%$ F3n\&optimize $=19960118 \&$ publicinterface $=$ true. Consultada el 21 de agosto de 2012. 
de ella la conclusión que ha de mantenerse por no ser ni correcta ni arbitraria, ni siquiera en un sentido profundo estar en pugna o contradicción con la confesión del matrimonio recurrido, ya que al admitir éstos que las fincas compradas otra vez en escritura pública 'pertenecían en realidad' al primer causante y transmitente, no contradice según ellos la segunda transmisión operada en su favor por el otro matrimonio, puesto que desde un principio reconocieron que esta segunda venta fue simulada y a los solos fines de instrumentar fehacientemente la primera y acceder al Registro de la Propiedad, dada su condición verbal y el fallecimiento del primer vendedor".

Y la sentencia del Tribunal Supremo de 12 de diciembre de $1983^{82}$ consideró:

"no pueden confundirse la falta de recibimiento a prueba y la denegación de alguna diligencia de prueba porque aun quebrantándose en uno y otro caso las formas esenciales del juicio el art. 1750 exige que se exprese el caso o casos del 1693 en que se funde y las reclamaciones que en referencia al mismo se hayan hecho para obtener la subsanación de la falta o que no fue posible hacerlas, conforme a lo prevenido en los 1696 y 1697, antecedentes tan inexcusables para la viabilidad de este extraordinario recurso de casación como variables según el caso o casos en que se funde; pero B) aún prescindiendo de tal defecto formal, aparte y además, la Sala de instancia resolvió acertadamente mediante sus autos de 14 octubre y 3 diciembre 1980, a tal punto que no hay sino asumir y dar por reproducidos sus propios fundamentados, siendo obvio que el requerimiento debatido pudo practicarse personalmente si se hubiere propuesto, como también pudo serlo, en el escrito de oposición a la ejecución y hecho efectivo simultáneamente con el otro requerimiento que sí fue practicado personalmente al demandante y con la prueba de confesión del mismo que precisó el desglose del documento que contenía las alusiones a esos otros documentos requeridos por el requerimiento, solicitado éste el día 28 abril o sea cuando no restaban sino 2 días $(29$ y 30 del mismo mes, siquiera el Juzgado computara hasta el 5 mayo y aún así entendiendo no había términos hábiles para diligenciar el exhorto); pero C) es que, acordado expresamente sin protesta de la parte el efectuarlo en la persona del procurador de su antagonista, se práctico a continuación y dentro de la misma fecha y con el beneplácito de la parte

${ }^{82}$ R.A., Valencia, Thomson Reuters-Aranzadi,1983, № 6930. 
interesada expresado paulatinamente en el escrito de súplica, lugar en que manifiesta que 'entendiéndose (la prueba) con el Procurador del demandante', 'nada tenía que impugnar, al ser válido el expresado requerimiento, conforme se argumentó en el escrito pidiendo el recibimiento a prueba en segunda instancia, en base al art. $6 .^{\circ}$ de la L.E. Civ., que dispone que el requerimiento hecho al Procurador tiene la misma fuerza que si interviniere en él directamente el poderdante', por lo cual concreta el agravio probatorio en 'que, como el demandante no ha aportado los documentos, de ahí la necesidad de pedir el recibimiento a prueba en segunda instancia, para que se practique nuevo requerimiento con el fin de conseguir su aportación'; instándose, en suma, -aunque confusamente- la compulsión al demandante para que aporte los documentos a que el requerimiento se refiere y sobre cuya mera existencia no se ha pronunciado el demandante ni resulta del documento en que se dicen aludidos donde se lee tener manifestado -no el requerido, sino esta parte- 'haber realizado varios pagos' que -admite el ejecutante- en principio, corresponden 'quizás al señor A. o un servidor Damián A. con motivo de otros documentos anteriores o posteriores y conversaciones verbales entre ambos', comprometiéndose -en esa hipótesis el demandante 'a abonarle la parte que me corresponda'-; aclarando la absolución a la posición 24 (85). 'Que lo único cierto es que el confesante le indicó (al demandante) que si algún pago tenía que pagarle (sic) que le correspondiera a él, que se lo justificara y que en el momento se lo pagaría, pero el confesante desconoce si le tiene que pagar algo', con cuyas palabras dejó en claro que no era él sino el propio ejecutado quien tenía que justificar los pagos de cargo del confesante; D) últimamente, el art. 603 que se invoca, no autoriza, siquiera por vía de contraste con el 602 , el que, dentro del juicio en que se intente hacerlos valer y a partir de la obligación en que los litigantes se hallan de aportar los documentos que sobren en su poder y sean del interés de la parte contraria, se lleve a efecto una pesquisa más allá de la ocupación del documento si se señala circunstancialmente su paradero".

c) Por medio de meras presunciones que lleven a la convicción del juzgador la falta de seriedad del contrato y la ausencia en el mismo del art. 1261.3 del Código Civilsupuesto contemplado en la sentencia del Tribunal Supremo de 24 de julio de $1989^{83}$ que indicó al respecto:

${ }^{83}$ Id Cendoj: 28079110011989100266. Se puede acceder en: www.poder judicial.es/search/ doAction? action $=$ contentpdf\&databasematch $=$ TS\&reference $=1170302 \&$ links $=$ en $\% 20$ 
“...la entrega de una participación de lotería implica un contrato de cesión de derechos realizada en el caso que nos ocupa por precio; en nuestra legislación, a partir del Ordenamiento de Alcalá, que inspira el vigente C. Civil, los contratos se perfeccionan y son obligatorios cualquiera que sea la forma en que se hayan celebrado, siempre que en ellos concurran las condiciones esenciales para su validez (art. 1278); la existencia o inexistencia del consentimiento, objeto y causa y, en definitiva, la del contrato, constituyen cuestiones de hecho que ha de apreciar el Juzgador de instancia y su criterio sólo puede combatirse al amparo del $\mathrm{n}^{\mathrm{o}} 4^{\mathrm{o}}$ del art. 1692 de la L.E.C., al menos en cuanto a los hechos que le sirvieron como soporte; no cabe sostener que el consentimiento se dio por motivos distintos de los que aparecen claramente expresados en el contrato, pues si existieran otros se habrían también consignado; el consentimiento manifestado en forma jocosa no vicia su existencia, ni la del objeto y la causa, cuando éstos resultan claros de aquella expresión y no cabe dudar de su validez, es decir, que el consentimiento 'iocandi causa' sólo revela la inexistencia del contrato cuando de él se desprenden la falta de objeto cierto que sea materia del mismo o la falta de causa de la obligación que se establezca, nada de lo cual se da en el presente caso, en el que el buen humor en la forma, como muestra de alegría y complacencia e incluso de la duda o esperanza sobre la buena suerte que haya de acompañar a los contratantes en el juego de la lotería, en nada empece a la seriedad del contrato".

Del mismo modo, la sentencia del Tribunal Supremo de 11 de junio de $1992^{84}$ entendió:

"La presunción de existencia de causa que establece dicho precepto sustantivo y su licitud, no es absoluta pues cede ante prueba en contrario, como sucede en los presentes autos, ya que el Tribunal de Apelación, del examen en conjunto de las probanzas aportadas y en su función juzgadora de interpretación del contrato arrendaticio controvertido, alcanzó la conclusión jurídica de que el mismo, por

nada $\% 20$ empece $\% 20 \mathrm{a} \% 201 \mathrm{a} \% 20$ seriedad $\% 20 \mathrm{del} \% 20$ contrato\&optimize=20051011\&publicinterface $=$ true. Consultada el 21 de agosto de 2012.

${ }^{84}$ Id Cendoj: 28079110011992104450. Se puede acceder en: www.poderjudicial.es/ search/doAction ?action $=$ contentpdf\&databasematch $=$ TS\&reference $=3065906 \&$ link $\mathrm{s}=\mathrm{del} \% 20$ examen $\% 20 \mathrm{en} \% 20$ conjunto $\% 20 \mathrm{de} \% 20$ las $\% 20$ probanzas $\% 20$ aportadas $\% 20$ $\mathrm{y} \% 20 \mathrm{en} \% 20 \mathrm{su} \% 20$ funci $\%$ F3n $\% 20$ juzgadora $\% 20 \mathrm{de} \% 20$ interpretaci $\%$ F3n $\% 20 \mathrm{del} \% 20$ contrato $\% 20$ arrendaticio $\% 20$ controvertido\&optimize $=20031025 \&$ publicinterface $=$ true . Consultada el 21 de agosto de 2012. 
simulado, era inexistente y nulo, al no darse la concurrencia de causa de la obligación que se establece en los contratos onerosos (arts. 1261 y 1274 del Código Civil), no produciendo efecto alguno la ausencia de causa (art. 1275), pues, con referencia al contrato de autos, no se da concurrencia de la función económico-jurídica que la causa representa.

La causa es requisito esencial en la constitución de los negocios contractuales y debe concurrir no sólo al tiempo de su formación sino, que también se precisa y subsista, durante la vida del convenio, hasta su total cumplimiento. De esta manera la Sala 'a quo' llegó al convencimiento y conclusión de la falta de seriedad del arriendo rústico que se celebró sin pretenderse los efectos propios e inherentes al mismo y como un medio que instrumentalizó el recurrente para continuar disponiendo y disfrutando con lucro la finca; por lo que al convenio le asisten todas las notas de apariencia y simulación que determinan la falta de causa y lo hacen nulo, conforme al art. 1261 del Código Civil, ya que da ausencia de uno de los requisitos esenciales y por tanto carece de valor alguno. $\mathrm{Al}$ estimarlo así la sentencia que se recurre, no ha producido infracción del art. 1277 del Código Civil, pues contra la presunción que sienta de existencia de causa, se alza prueba contundente en contrario y que la propia sentencia analiza y admite; con lo que la argumentación fracasa [SS. 14 de marzo de 1958 (RJ 1958\1080), 22 de febrero de 1963 (RJ 1963\827), 20 de enero de 1965 (RJ $1965 \backslash 160), 25$ de junio de 1969 (RJ 1969 \3641), 11 de mayo de 1970 (RJ 1970\2280), 20 de diciembre de 1983 (RJ 1983\6968), 26 de febrero de 1987 (RJ 1987 740), 4 de mayo de 1987 (RJ 1987 $\backslash 3175$ ), 5 de noviembre de 1988 (RJ 1988\8418) y 19 de julio de 1989 (RJ 1989\5726)].

En todo caso el problema de la existencia de causa es de mero hecho, favorecido por una presunción que desplaza su prueba al que la alega y resultó cumplida en estas actuaciones [SS. 17 de noviembre de 1983 (RJ 1983\6118), 14 de febrero de 1985 (RJ 1985\553), 12 de febrero y 16 de septiembre de 1988 (RJ $1988 \backslash 942$ y RJ 1988\6689) y 31 de marzo de 1991 (RJ 1991\522)]".

Entraría en juego lo dispuesto en el art. 1275 del Código Civil, de conformidad con lo que dispone la sentencia del Tribunal Supremo de 19 de noviembre de $1990^{85}$ :

${ }^{85}$ Id Cendoj: 28079110011990100680. Se puede acceder en: www.poderjudicial. es/search/doAction ?action $=$ contentpdf $\&$ databasematch $=$ TS\&reference $=1171468 \&$ lin 
“...siendo doctrina reiterada y unánime de esta Sala la de que 'si bien es cierto que el art. 1277 del Código Civil establece una presunción legal a favor de la existencia y licitud de la causa en los negocios jurídicos y exonera a los favorecidos por ella de la carga de la prueba, no lo es menos que se admite la posibilidad de que se acredite lo contrario, cosa que puede llevarse a efecto por cualquiera de los medios que se enuncian en el art. 1215 del Código Civil e incluso a través de las manifestaciones de los interesados en sus respectivos escritos -sentencias, entre otras, de 25 de junio de 1969 (RJ 1969\3641), 20 de diciembre de 1983 (RJ 1983\6968), 2 de febrero de 1984 (RJ 1984\569)- o por medio de meras presunciones que lleven a la convicción del Juzgador la falta de seriedad del contrato y la ausencia en el mismo del tercero de los requisitos del art. 1261 del Código Civil con lo que entraría en juego lo previsto en el art. 1275 del propio Cuerpo legal' -sentencia de 26 de febrero de 1987 (RJ 1987\740)-, y si bien, de acuerdo con la doctrina de esta Sala, la apreciación de la existencia o inexistencia de causa o la concurrencia de una causa falsa está atribuida al Tribunal 'a quo' por ser de naturaleza fáctica, al no haber enjuiciado las sentencias de instancia la cuestión planteada, sobre la existencia o inexistencia de causa en el contrato, no han establecido los datos fácticos de que pueda resultar tal concurrencia o defecto de causa, por lo que esta Sala, con función casacional, tiene según su propia doctrina, acceso a la apreciación directa de las actuaciones para formular declaraciones de hechos, cuando por defecto u omisión del juzgador de instancia, no se haya definido con exactitud y la debida extensión y profundidad la historia circunstanciada del sustratum fáctico que anida en la relación material o de fondo de cualquier controversia resuelta judicialmente -sentencia entre otras, de 2 de junio de 1981 (RJ 1981 $\backslash 2490), 17$ de febrero de 1982 (RJ 1982\742), 15 de julio de 1983 (RJ 1983\4229), 4 de abril de 1984 (RJ 1984\1927), 26 de mayo y 16 de septiembre de 1988 (RJ 1988\6690)-”.

Podemos encontrar sentencias en las que se exprese que no cabe la confusión entre la causa ilícita y la causa falsa. La causa ilícita requiere la efectiva existencia de causa aunque viciada por ser contraria a las leyes o a la moral. La causa falsa supone la inexistencia de causa.

$\mathrm{ks}=\mathrm{y} \% 20$ profundidad $\% 201 \mathrm{a} \% 20$ historia $\% 20$ circunstanciada $\% 20$ del $\% 20$ sustratum $\% 20$ $\mathrm{f} \%$ E1ctico\&optimize $=20051011$ \&publicinterface $=$ true. Consultada el 21 de agosto de 2012. 
Una de las sentencias en las que se declara esta postura es la sentencia del Tribunal Supremo de 14 de junio de $1997^{86}$ :

“...Para estimar causa contractual ilícita ha de partirse de la concurrencia efectiva de causa, pero ésta resulta viciada por ser contraria a las leyes o a la moral en su conjunto, cualesquiera que sean los medios empleados para lograr tal finalidad, elevándose el móvil a la categoría de causa en sentido jurídico, conforme declaró la Sentencia de 13 de marzo de 1997 (RJ 1997\2103) (que cita las de 8 de febrero de 1963 [RJ 1963\963], 2 de octubre de 1972 [RJ 1972\3907], 22 de noviembre de 1979 [RJ 1979\4309], 14 de marzo y 11 de diciembre de 1986 [RJ 1986\1252 y RJ 1986\7432]), ya que el móvil impulsa la voluntad reprochable del convenio alcanzado, con lo que la ilicitud causal tiene apoyo en la finalidad negocial ilegal o inmoral que se pretende, común a todas las partes obligadas...

No cabe confundir la causa falsa con el móvil de defraudar los derechos ajenos (de naturaleza subjetiva), ya que la causa es la razón esencial del contrato (sentencia de 30 de enero de 1960 [RJ $1960 \backslash 895]$ ). La falsedad de la causa se contrapone a la verdadera que refiere el artículo 1274 del Código, equivaliendo a su no presencia, operando como sinónima de simulación, que hace que el contrato no tenga existencia jurídica, que es lo que aquí se trata, es decir de relaciones arrendaticias totalmente ineficaces (SSTS 21 marzo 1956 [RJ 1956\1520] y 10 de diciembre de 1996 [RJ 1996\8846]), toda vez que la causa que se expresó no es sólo aparente, sino falsa.

La total ausencia de precio ocasiona la nulidad absoluta de los negocios (SS. 11 de diciembre de 1986 [RJ 1986\7432], 31 de enero de 1991 [RJ 1991\522], 10 de noviembre de 1992 [RJ 1992\8962], 6 de octubre de 1994 [RJ 1994\7459] y 4 de abril de 1994, entre otras...”.

\section{Conclusiones}

Resulta especialmente complejo poder llegar a definir y conceptualizar los términos de 'ineficacia', 'invalidez', 'inexistencia', 'nulidad' y 'anulabilidad' por parte de la doctrina. Las posturas oscilan entre considerar que son

${ }^{86}$ Id Cendoj: 28079110011997102381. Se puede acceder en: www.poderjudicial.es/ search $/$ doAction ?action $=$ contentpdf $\&$ databasematch $=T S \&$ reference $=2942445 \&$ links $=$ estimar $\% 20$ causa $\% 20$ contractual $\% 20$ il $\%$ EDcita $\% 20$ ha $\% 20$ de $\% 20$ partirse $\% 20 \mathrm{de} \% 20$ la $\% 20$ concurrencia $\% 20$ efectiva\&optimize $=20031203 \&$ publicinterface $=$ true. Consultada el 21 de agosto de 2012. 
términos en los que uno incluye al otro, hasta que la apreciación de ambas categorías no es necesaria, ya que se debe atender al plano práctico y no al teórico, en el que se situaría la invalidez. En sede contractual, la invalidez supondría la ineficacia, pero no toda ineficacia supondría invalidez. La necesidad de diferenciar estos términos y categorizar la inexistencia ha sido una materia que no se ha aclarado con las aportaciones doctrinales. Ha sido, más bien, la jurisprudencia la que ha conceptualizado la inexistencia, y que ha sido precisamente el soporte del que se ha valido un sector minoritario, al que seguimos.

Para perfilar un poco mejor esta conceptualización, hemos acudido a la regulación de la nulidad textual francesa (pas de nullité sans texte), cuya influencia se percibe en la redacción del Código Civil español, especialmente en el caso de la regulación de la causa ilícita, considerado como supuesto de nulidad textual. No obstante, el desarrollo práctico de la nulidad textual adoleció de algunos defectos, por lo que a la rigidez que conllevaba, surgió el concepto de la inexistencia, con la finalidad de paliarlo, y evitar que se quedaran sin sanción irregularidades no contempladas en la norma. La llamada nulidad virtual como nulidad implícita y no explícita, como suponía la textual, extiende el control de la legalidad a supuestos en los que quedaban sin sanción por la nulidad textual.

La regulación de dichas categorías en el ordenamiento jurídico español adolecen de la falta de precisión y definición -ello, aunque la doctrina lo ha calificado de positivo que no exista una definición exacta-, sí que podemos indicar que hubiera resultado útil y oportuno que se hubieran caracterizado los casos y condiciones para el régimen de ineficacia, recogiendo el concepto general de cada tipo y del régimen aplicable.

Todo ello lo que ha provocado es que a lo largo de todas las aportaciones que se han estudiado, se utilice, con total imprecisión, los términos de 'ineficacia', 'inexistencia', 'invalidez', 'nulidad', 'anulabilidad'... no deslindándose de forma clara cada supuesto. En el Código Civil se deduce el concepto de inexistencia en los arts. 1261, 1275, en relación con los artículos que regulan la nulidad absoluta. La doctrina considera que ello fue motivado para poder distinguir los casos de nulidad radical, nulidad en sentido absoluto y la nulidad relativa o anulabilidad.

La inexistencia se categoriza para superar la imprecisión terminológica del texto legal, y diferenciarse de la nulidad absoluta y relativa, y para evitar que se aplicara a supuestos de nulidad absoluta el régimen jurídico de la anulabilidad.

La inexistencia no va a coincidir siempre con la nulidad absoluta, ya que la ineficacia (como categoría genérica) que provenga de la inexistencia no va a ser igual que la derivada de la contravención legal, pues en el supuesto de inexistencia, los contratantes van a poder completar el contrato 
(si falta un requisito esencial), y en el segundo supuesto (contravención), no es posible que completen el mismo.

Hay que distinguirla también la inexistencia de la ilegalidad, ya que en la primera se produce una ausencia de un componente intrínseco del supuesto de hecho contractual, mientras que en el segundo caso tiene que darse la existencia de dichos componentes. La falta de requisitos esenciales en el contrato que indica el art. 1261 del Código Civil es considerado como inexistencia por parte de alguna jurisprudencia y la doctrina más reciente. Sin embargo, también nos encontramos con sentencias en las que se inclinan por considerar a la nulidad absoluta y a la inexistencia como términos equivalentes, así como considerar a la inexistencia como una "variedad" de invalidez junto a la nulidad absoluta y la anulabilidad.

La inexistencia se utiliza por la jurisprudencia para aplicarla a contratos simulados, con la finalidad de evitar la caducidad de la acción del art. 1300 y ss. del Código Civil.

\section{JURISPRUDENCIA}

Sentencia del Tribunal Supremo de 22 de marzo de 1924.

Sentencia del Tribunal Supremo de 21 de marzo de 1952.

$110 \quad$ Sentencia del Tribunal Supremo de 7 de diciembre de 1965.

Sentencia del Tribunal Supremo de 27 de diciembre de 1966.

Sentencia del Tribunal Supremo de 25 de junio de 1979.

Sentencia del Tribunal Supremo de 18 de diciembre de 1981.

Sentencia del Tribunal Supremo de 14 de marzo de 1983.

Sentencia del Tribunal Supremo de 12 de diciembre de 1983.

Sentencia del Tribunal Supremo de 2 de febrero de 1984.

Sentencia del Tribunal Supremo de 29 de abril de 1986.

Sentencia del Tribunal Supremo de 8 de julio de 1987.

Sentencia del Tribunal Supremo de 11 de marzo de 1988.

Sentencia del Tribunal Supremo de 24 de julio de 1989.

Sentencia del Tribunal Supremo de 19 de noviembre de 1990.

Sentencia del Tribunal Supremo de 24 de febrero de 1992.

Sentencia del Tribunal Supremo de 11 de junio de 1992.

Sentencia del Tribunal Supremo de 27 de febrero de 1997.

Sentencia del Tribunal Supremo de 29 de abril de 1997.

Sentencia del Tribunal Supremo de 14 de junio de 1997.

Sentencia del Tribunal Supremo de 21 de octubre de 1997.

Sentencia del Tribunal Supremo de 23 de diciembre de 1997. 


\section{BibLIOGRAFÍA}

Albaladejo García, Manuel, El negocio jurídico, Barcelona, Editorial Bosch, 1958.

Albaladejo García, Manuel, "Invalidez de la declaración de voluntad", en Anuario de Derecho Civil, tomo x, fascículo Iv, Madrid, octubre-diciembre 1957.

Amorós Guardiola, Manuel, Comentarios a las reformas del Código Civil, Madrid, Editorial Tecnos, 1977, vol. I.

BetTi, Emilio, Teoría general del negocio jurídico, traducción y concordancias con el Derecho español por A. Martín Pérez, Madrid, Editorial Revista de Derecho Privado, 1959.

Bonel y Sánchez, León, Código civil español comentado y concordado, Barcelona, López Robert, 1891, tomo IV, libro IV.

Borrell y Soler, Antonio María, La nulidad de los actos jurídicos según el Código civil español, Barcelona, Editorial Bosch, 1947.

Casado CASAdo, Belén, "El art. 6.3 CC, ¿ punto de partida para el establecimiento de un régimen sancionador en el Código Civil?", en Nul: estudios sobre invalidez e ineficacia, $\mathrm{N}^{\mathrm{o}} 1$, ejemplar dedicado a Coloquios, 2006. En www.codigo-civil. info/nulidad/lodel/document.php?id=229.

Castán Tobeñas, José, Derecho civil español, común y foral, reimpresión de la $14^{\mathrm{a}}$ ed., revisada y puesta al día por José Luis de los Mozos, Madrid, Editorial Reus, 1987, tomo I: Introducción y parte general, Teoría de la relación jurídica. La persona y los derechos de la personalidad. Las cosas. Los hechos jurídicos, vol. $2^{\circ}$.

Clemente de Diego, Felipe, Instituciones de Derecho civil español, Derecho de obligaciones, Contratos, Derecho de familia, Madrid, s.n., 1959, tomo II.

De Castro y Bravo, Federico, El negocio jurídico, Madrid, Editorial Civitas, 1971.

De Los mozos y De Los mozos, José Luis, "Inexistencia, nulidad y anulabilidad en el Anteproyecto de Código Europeo de Contratos de la Academia de Pavía", en José Manuel GonZález PorRas y Fernando P. Méndez GonZÁlez (coords.), Libro Homenaje al profesor Manuel Albaladejo García, Murcia, Universidad de Murcia, 2004, vol. 2.

De Morató, Domingo, Derecho civil español con las correspondencias del Derecho romano, Valladolid, Editorial Imprenta, Librería Nacional y Extrangera de Hijos de Rodríguez, Libreros de la Universidad y del Instituto, 1877.

Delgado Echeverría, Jesús, "Comentario al artículo 1300 del Código civil”, en Manuel Albaladejo (dir.), Comentarios al Código civil y Compilaciones forales, artículos 1281 a 1314 del Código civil, Madrid, Editoriales de Derecho Reunidas, 1981, tomo XVII, vol $2^{\circ}$.

Delgado Echeverría, Jesús, Elementos de Derecho civil, Derecho de Obligaciones, Contratos y cuasicontratos, Delito y cuasidelito, $2^{\mathrm{a}}$ ed., Barcelona, Editorial Bosch, 1990, tomo II, vol. $2^{\circ}$.

Delgado Echeverría, Jesús, "Inexistencia, nulidad y anulabilidad. Usucapión: justo título. Causa ilícita. Venta de cosa ajena. Comentario STS 14 marzo 1983", en Cuadernos Civitas de Jurisprudencia Civil, No 2, Navarra, abril-agosto 1983. 
Delgado Echeverría, Jesús y Ma Ángeles, Parra Lucán, Las nulidades de los contratos. En la teoría y en la práctica, Madrid, Dykinson, 2005.

Di Marzo, Salvatore, Le basi romanistiche del Codice Civile, Torino, Editoriale Unione Tipográfica-Editrice, 1950.

DíEz-PicAzo y Ponce De León, Luis, "Eficacia e ineficacia del negocio jurídico", en Anuario de Derecho Civil, tomo XIV, fascículo IV, Madrid, octubre-diciembre 1961.

Díez-Picazo y Ponce de León, Luis, Fundamentos del Derecho civil patrimonial, Introducción. Teoría del contrato, $5^{\mathrm{a}}$ ed., Madrid, Civitas, 1996, vol. I.

Díez-Picazo y Ponce de León, Luis y Antonio Gullón Ballesteros, Sistema de Derecho civil, El contrato en general. La relación obligatoria. Contratos en especial. Cuasicontratos. Enriquecimiento sin causa. Responsabilidad extracontractual, $9^{\mathrm{a}} \mathrm{ed}$, Madrid, Tecnos, 2002, vol. II.

Díez-Picazo y Ponce de León, Luis y Antonio Gullón Ballesteros, Sistema de Derecho civil, Introducción. Derecho de la personal. Autonomía privada. Persona jurídica, $11^{\mathrm{a}}$ ed., Madrid, Tecnos, 2003, vol. I.

Egusquiza Balmaseda, María Ángeles, Cuestiones conflictivas en el régimen de la nulidad y la anulabilidad del contrato, Navarra, Editorial Aranzadi, 1999.

FAlCón, Modesto, Código civil español, Madrid, Editorial Góngora, 1889, tomo IV.

FEDELE, Alfredo, La invalidità del negozio giuridico di diritto privato, Torino, Editoriale G. Giappichelli, 1943.

FErrara, Francesco, Teoría del negozio illecito nel diritto civile italiano, $2^{\mathrm{a}}$ ed., Milano, Societa Editrice Libraria, 1914.

García Amigo, Manuel, Lecciones de Derecho civil, Teoría general de las obligaciones y contratos, Madrid, Editorial McGraw Hill, 1995, vol. II.

Gete-Alonso y Calera, María del Carmen, Manual de Derecho civil, Madrid, Marcial Pons, 1996.

Gordillo Cañas, Antonio, "Nulidad, anulabilidad e inexistencia (El sistema de las nulidades en un Código latino situado entre la primera y la segunda Codificación)", en Centro de Estudios Ramón Areces (ed.), Centenario del Código civil (1889-1989), Madrid, Editorial Ramón Areces, 1990, tomo I.

Gordillo CaÑas, Antonio, "Violencia viciante, violencia absoluta e inexistencia contractual”, en Revista de Derecho Privado, vol. 67, Madrid, marzo 1983.

Grimalt Servera, Pedro: "Nulidad y anulabilidad en el Código civil. Revisión crítica de la categoría de la anulabilidad, de acuerdo con el texto que se adjunta", en Nul: estudios sobre invalidez e ineficacia, $\mathrm{N}^{\mathrm{0}}$ 1, 2009, p. 1. En www. codigo-civil.info/nulidad/lodel/docannexe.php?id=739.

LAVANDERA y Blanco, Víctor, "Nulidad, anulabilidad y rescindibilidad en el Código civil”, en Revista de Derecho Privado, N 6, Madrid, 15 de marzo de 1914.

Lacruz Berdejo, José Luis, Francisco de Asís Sancho Rebullida, Agustín Luna Serrano, Jesús Delgado Echeverría, Francisco Rivero Hernández y Joa- 
quín Rams Albesa, Elementos de Derecho civil, Derecho de Obligaciones, Contratos y cuasicontratos. Delito y cuasidelito, Madrid, Dykinyson, 2005, tomo II, vol. $2^{\circ}$.

LAREnZ, Karl, Tratado de Derecho civil alemán, traducción Miguel Izquierdo, Madrid, Editorial Revista de Derecho Privado, 1978, Parte general.

Lasso Gaite, Juan Francisco, Crónica de la codificación española, codificación civil (génesis e historia del Código), Madrid, Editorial Ministerio de Justicia, Comisión General de Codificación, 1970, vol. II, N 4 .

Martín Retortillo, Cirilo, "Algo sobre las acciones de inexistencia en el Derecho civil", en Pedro Font y Puig, Estudios Jurídicos, conferencias de los cursillos de los años 1950 y 1951 del Colegio Notarial de Barcelona, Barcelona, Colegio Notarial de Barcelona, 1959.

Miguel Traviesas, Manuel, "Sobre nulidad jurídica", en Revista General de Legislación y Jurisprudencia, $\mathrm{N}^{\mathrm{O}}$ 125, Madrid, 1914.

Morales Hervías, Rómulo, "Inexistencia y nulidad analizadas desde el punto de vista de los derechos italiano, español y peruano", en Nul: estudios sobre invalidez e ineficacia, ejemplar dedicado a estudios, $\mathrm{N}^{\mathrm{o}} 1,2005$, p. 1 y ss. En www.codigo-civil.info/nulidad/lodel/document.php?id=129.

Morales Moreno, Antonio Manuel, “Comentario al artículo 1261 del Código civil”, en Cándido Paz-Ares Rodríguez, Luis Díez-Picazo y Ponce de León, Rodrigo Bercovitz Rodríguez-Cano y Pablo Salvador Coderch (dirs.), Comentario del Código civil, $2^{\mathrm{a}}$ ed., Madrid, Editorial Ministerio de Justicia, Secretaría General Técnica, 1993, tomo II.

Moreno LuQue, Carmen, "Notas sobre la eficacia e ineficacia del negocio: inexistencia, nulidad, anulabilidad y rescisión”, en Actualidad civil, $\mathrm{N}^{\mathrm{o}} 38$, Madrid, semana 13-19 de octubre 1986.

Moreno Mocholí, Miguel, "Las 'irregularidades' en el negocio jurídico”, en Revista de Derecho Privado, No 346, Madrid, enero 1946.

Oyuelos, Ricardo, Principios, doctrina y jurisprudencia referentes al Código civil español, Madrid, Editorial Cuerpo del Derecho Español, 1928, tomo V.

Pasquau Liaño, Miguel, Nulidad y anulabilidad del contrato, Madrid, Editorial Civitas, 1997.

Planas y Casals, José María, Derecho civil español común y foral, Barcelona, Editorial Librería Bosch, 1925, tomo II.

Puig Brutau, José, Diccionario de acciones en Derecho civil español, Barcelona, Editorial Bosch, 1984.

Puig Brutau, José, Fundamentos de Derecho civil, Doctrina general del contrato, Barcelona, Editorial Bosch, 1954, tomo II, vol. $1^{\text {O }}$.

Quicios Molina, Susana, "La ineficacia contractual”, en Rodrigo Bercovitz RoDríguez-Cano (dir.), Nieves Moralejo Imbernón y Susana Quicios Molina (coords.), Tratado de Contratos, Concepto, limites, significación, requisitos, formación, forma, documentación, interpretación e integración, eficacia e ineficacia del contrato, Valencia, Tirant lo Blanch, 2009, tomo I. 
Rattin, Livio, Sugli effetti dei negozi nulli, Bologna, Editoriale Pàtron, 1983.

Santoro Passarelli, Francesco, Doctrinas generales del Derecho civil, traducción y concordancias de Derecho español por A. Luna Serrano, Madrid, Editorial Revista de Derecho Privado, 1964.

SAntos Briz, Jaime, Derecho civil. Teoría y práctica, Madrid, Editorial Edersa, 1978, tomo I.

Valpuesta Fernández, María Rosario, "Ineficacia del contrato", en AA.VV., Derecho civil, Derecho de obligaciones y contratos, Valencia, Editorial Tirant lo Blanch, 2001.

Valverde y Valverde, Calixto, Tratado de Derecho civil Español, Valladolid-Madrid, Editorial Cuesta, 1913, tomo III: Parte especial, Derechos personales o de obligaciones.

Vattier Fuenzalida, Carlos, "Inexistencia y nulidad del contrato", en Carlos Vattier Fuenzalida, José María de la Cuesta Sáenz y José María Caballero LozAno (coords.), Código europeo de contratos: comentarios en homenaje al prof. $D$. José Luis de los Mozos y de los Mozos, Madrid, Dykinson, 2003, vol. 2.

Vattier Fuenzalida, Carlos, "Inexistencia y nulidad del contrato. Estudio del anteproyecto de Pavía", en Juan Manuel Abril Campoy y María Eulalia Amat Llari (coords.), Homenaje al profesor Lluis Puig i Ferriol, Valencia, Tirant lo Blanch, 2006, vol. 2.

114 VázQuez de CASTRo, Eduardo, Ilicitud contractual. Supuestos y efectos, Valencia, Editorial Tirant lo Blanch, 2003. 